TERMINUS

t. 19 (2017), z. 3 (44), s. 567-607

doi: $10.4467 / 20843844$ TE. 17.016 .8883

www.ejournals.eu/Terminus

Karol Łopatecki

Uniwersytet w Białymstoku

k.lopatecki@uwb.edu.pl

\title{
Mapy w planowaniu działań operacyjnych armii polskiej i litewskiej do początków panowania Stefana Batorego ${ }^{1}$
}

\begin{abstract}
The Use of Maps in the Planning of Operational Activities of Polish and Lithuanian Armies Until the Beginning of the Rule of Stephen Báthory
\end{abstract}

As per the $16^{\text {th }}$ and $17^{\text {th }}$ centuries, operational activities should be understood as military activities conducted by independent groups (usually regiments). They may also be termed the art of manoeuvre. One may place them between strategic decisions and specific tactic actions related to fighting a battle or conducting a siege. The first mid-16 ${ }^{\text {th }}$-century theoreticians to have observed the importance of this art were Albrecht Hohenzollern and Andrzej Frycz Modrzewski. Some $16^{\text {th }}$-cenutry authors (e.g. Jan Tarnowski, Albrecht Hohenzollern, Marcin Bielski) concordantly postulated the introduction of a preceding manoeuvre action that would last one day. This assumption survived until the early $18^{\text {th }}$ century.

${ }^{1}$ Artykuł powstał w ramach projektu badawczego Narodowego Centrum Nauki Opus (nr 2014/15/B/HS2/01104) Związki literatury polskiej i kartografii w XVI I pot. XVII $w$. 
As early as in 1551, Modrzewski proposed to follow the Turkish example and make special maps for the purposes of the moving army. Apart from the Turks, caesarean experiences were also mentioned. Bartosz Paprocki and Andrzej Gostyński quoted mainly the example of Charles V (1500-1558). Bartosz Paprocki and Stanisław Sarnicki, in turn, writers active at the beginning of the rule of Stephen Báthory, opted for the necessity of having a cartographer in the army who would make march route maps au courant. The cartographic turn in manoeuvre activities took place in 1567-1577, during the war fought against the rebellious Gdańsk. According to our knowledge, five different maps and plans were made in this period.

The production of march route maps required measuring distances with steps, which greatly facilitated reconnoitring. Uniform march step enabled even the determination of the distance covered on the basis of the time lapsed. Engineers could have used an aid in the form of pedometers that counted the number of steps of a man or a horse. These assumptions were disseminated in the Polish-Lithuanian Commonwealth by Marcin Bielski who quoted an ancient Roman concept of a double step (passus - $148 \mathrm{~cm}$ ).

Keywords: operational activities, war in the $16^{\text {th }}$ century, military cartography, theoreticians of military science in the $16^{\text {th }}$ century, itineraries

Sztuka operacyjna jest najmłodszą, wyodrębnioną na początku XX wieku, dziedziną sztuki wojennej. Zajmuje się ona operacją i zasadami dowodzenia wojskami w operacjach ${ }^{2}$. Fakt, że dopiero w ubiegłym stuleciu zdefiniowano i zaczęto badać to zjawisko, nie oznacza, że de facto nie występowało ono wcześniej ${ }^{3}$ W związku ze zmianami

2 J. Zieliński, Zarys teorii sztuki operacyjnej wojsk ladowych Rzeczpospolitej Polskiej, Torun 1998; T. Kośmider, J. Ślipiec, Operacje wojsk lądowych w pogladach przedstawicieli europejskiej myśli wojskowej od XVIII wieku do wybuchu drugiej wojny światowej, Warszawa 2008; M. Wiatr, Między strategia a taktyka, Torun 1999; A. Polak, Sztuka wojenna. Kontekst teoretyczny i praktyczny, „Zeszyty Naukowe AON" (2013), nr 3(92), s. 219-228.

${ }^{3} \mathrm{~W}$ naukach historycznych akcentuje się niebezpieczeństwo ahistoryzmu, a nawet postuluje się zaniechanie używania pojęcia "działania operacyjne" w odniesieniu do okresu feudalnego. Przegląd ocen historyków z pozytywną konkluzją, jeśli chodzi o analizowanie wczesnonowożytnych działań wojennych przez pryzmat „operacji”: J. Maroń, Kłuszyn i Cudnów a operacyjny wymiar wojny w epoce wczes- 
technologicznymi, organizacyjnymi, komunikacyjnymi i intelektualnymi oczywiste jest, że pojęcie to stosowane $\mathrm{w}$ analizie konfliktów z XXI stulecia ma nieco inny charakter niż w wieku XVI czy XVII Dlatego termin „sztuka operacyjna” wymaga na wstępie doprecyzowania.

Sądzę, że kluczową rolę odgrywają poglądy teoretyków, którzy już w okresie nowożytnym zaczęli dostrzegać pewien zespół działań niewchodzących bezpośrednio w zakres ani pojęcia strategii, ani taktyki. Wskazuje się, że pierwsze historyczne wyjaśnienie terminu „działania operacyjne” wiązać należy z poglądami Henry’ego Humphreya Lloyda, który na podstawie doświadczeń wojny siedmioletniej uznał je za „określoną formę działań prowadzonych przez samodzielne zgrupowania" ${ }^{\circ}$. Operacja stanowiła wszelkie działania łączące bazę operacyjną z punktem docelowym, a te czynności manewrowe nazywamy liniami operacyjnymi (il. 1). Zjawisko to opi-

nonowożytnej, w: Studia z dziejów stosunków Rzeczypospolitej z Państwem Moskiewskim w XVI-XVII wieku, red. M. Nagielski, K. Bobiatyński, P. Gawron, Zabrze-Tarnowskie Góry 2013, s. 278-289.

${ }^{4} \mathrm{~W}$ drugiej połowie XX wieku przez pojęcie operacji rozumiano „zgranie kilku walk bądź kilkudniowych serii walk, poprowadzonych oddzielnie na kilku zbieżnych kierunkach, nieraz bardzo odległych od siebie. Ta kombinacja wielokierunkowego działania kilku zgrupowań o różnej sile dla osiągnięcia jednego celu stanowi zasadniczą istotę operacji”. Używano również szerszej definicji: „całokształt poczynań organizacyjno-wykonawczych, wiele bitew, walk, uderzeń ogniowych i manewrów wykonywanych samodzielnie lub kilkoma związkami operacyjnymi różnych rodzajów wojsk i sił zbrojnych, połączonych zamiarem dowódcy, w celu rozbicia operacyjnego zgrupowania wojsk nieprzyjaciela $\mathrm{w}$ określonym miejscu (rejonie, kierunku) i czasie, dla osiągnięcia konkretnego celu operacyjnego lub strategicznego przy jak najmniejszych stratach własnych". S. Mossor, Sztuka wojenna w warunkach nowoczesnej wojny, Warszawa 1986, s. 199; to samo: K. Nożko, Walka o przewage, Warszawa 1985, s. 32.

${ }^{5}$ J. Zieliński, Zarys teorii sztuki operacyjnej..., s. 22; także: H. Hermann, Operacyjny wymiar walki zbrojnej, Toruń 2004, s. 62; A. Polak, Sztuka wojenna..., s. 225. Por. J. Ślipiec, T. Kośmider, Generat Henry Humphrey Evans Lloyd - jako prekursor teorii operacji w europejskiej myśli wojskowej. (Doświadczenia), „Myśl Wojskowa” 62 (2006), $\mathrm{nr} 6$, s. 169-178. 
sywał już w drugiej połowie XVII stulecia Raimondo Montecuccoli. Według tego wodza przez termin „operacja” należało rozumieć takie manewrowanie, które polepszało sytuację własną i stawiało nieprzyjaciela w złym położeniu. Istotą operacji było unikanie bitwy generalnej przy jednoczesnym przejęciu linii dostaw i zaopatrzenia oraz osłabieniu morale przeciwnika ${ }^{6}$. Z punktu widzenia średniowiecznych i nowożytnych badań wojskowych jest to najprostsze, a równocześnie najlepsze założenie. Dowódcy wszelkich wyodrębnionych organizacyjnie armii musieli podejmować decyzje dotyczące bieżącej działalności, co w pewnym uproszczeniu możemy określać jako sztukę manewrowania. Wypełniała ona ogromny obszar działań pomiędzy opracowaniem przez władcę, naczelnego wodza, radę wojenną strategicznych celów wojny a działaniami taktycznymi związanymi z koniecznością przeprowadzenia bitew czy też działań oblężniczych.

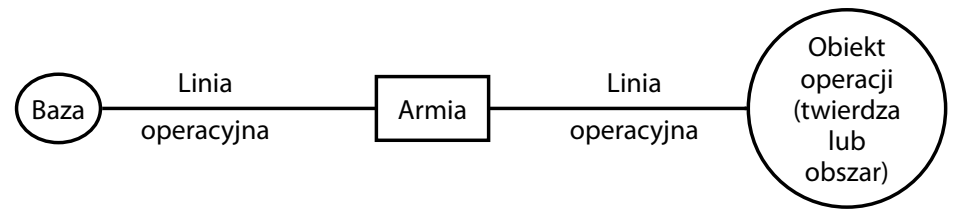

Il. 1. Operacje w świetle poglądów Henry’ego Humphreya Lloyda (opracowanie własne na podstawie schematu M.N. Vego, Joint Operational Warfare. Theory and Practice, Newport 2007, s. V-12)

W niniejszym artykule prezentuję wykorzystanie kartografii w wojskowości polsko-litewskiej do działań operacyjnych. Skupiam się przy tym na najwcześniejszym okresie, obejmującym czasy do początku panowania Stefana Batorego. Wówczas wytworzył się pogląd o konieczności wykorzystania map i planów w działaniach

${ }^{6}$ G.E. Rothenberg, Maurice of Nassau, Gustavus Adolphus, Raimondo Montecuccoli, and the "Military Revolution" of the Seventeenth Century, w: Makers of Modern Strategy. From Machiavelli to the Nuclear Age, ed. by P. Paret, Princeton 1986, s. 55-63; M.N. Vego, Joint Operational Warfare. Theory and Practice, Newport 2007, s. V-11-V-12. 
manewrowych, co w pełni po raz pierwszy zastosowano w trzech wyprawach Batorego na państwo moskiewskie (1579-1582).

W mojej ocenie w Europie Środkowej szesnastowiecznym teoretykiem, który dobrze rozumiał i dostrzegał wagę działań operacyjnych (jakkolwiek jeszcze tak nienazywanych), był książę Albrecht Hohenzollern. Bardzo szczegółowo opisał on potrzebę funkcjonowania przy armii grupy rozpoznawczej, w której skład wchodziliby inżynierowie. Mieli być oni odpowiedzialni między innymi za właściwe przygotowanie dróg. Urzędnikiem zobowiązanym do dbałości o przejezdność szlaków i zakładanie obozów był szancmistrz lub oboźny. Według księcia pruskiego oddział rozpoznawczy powinien być oznaczony specjalnym proporcem (refanem) i poruszać się przed czołem głównych sił. Książę ocenił, że szancmistrzowi i oboźnemu oprócz ich sług powinni towarzyszyć ludzie dobrze znający drogę, a także lekka jazda, która ma przeglądać okolicę, „szpiegując dróg a ścieżek tajemnych, jeśli się nieprzyjaciel gdziekolwiek nie zataił a schował"7. Wyznaczanie marszruty powinno następować z dziennym wyprzedzeniem, co pozwalałoby kontrolować przepływ informacji i uniemożliwiałoby wrogowi podejmowanie działań utrudniających pochód armii. Dodatkowo w grupie rozpoznawczej powinno się znajdować sześć wozów z przyborami do budowy mostów, co zostało zresztą zrealizowane w praktyce w czasie wyprawy pozwolskiej w 1557 roku $^{8}$. Należy podkreślić, że do budowy mostów niezbędna była wiedza właściwa inżynierowi wojskowemu. Inżynierowie powinni w pierwszej kolejności zmierzyć szerokość rzeki za pomocą sznura mierniczego, a w razie opanowania brzegu przez

7 Die Kriegsordnung des Markgrafen zu Brandenburg Ansbach und Herzogs zu Preussen Albrecht des Älteren - Königsberg 1555, Bd. 1, hrsg. von H.J. Bömelburg, B. Chiari, M. Thomae, Braunschweig 2006, s. 198.

${ }^{8}$ Ibidem, s. 198, 205-206, 209-210, 234-235; T.M. Nowak, Uwagi o technice budowy mostów polowych w Polsce w w. XV do XVII, ,Studia i Materiały do Historii Sztuki Wojennej” 2 (1956), s. 360. 
nieprzyjaciół za pomocą laski mierniczej (baculus Jacobi - laski Jakubowej) ${ }^{9}$.

Podsumowując, według Albrechta Hohenzollerna armii powinna towarzyszyć grupa wywiadowcza, która nie tylko rozpoznawała $\mathrm{z}$ jednodniowym wyprzedzeniem teren, ale również była odpowiedzialna za przygotowanie dróg, a także proponowała marszrutę i potencjalnie wybór miejsca na obozowisko. Grupa ta odgrywała szczególnie istotną rolę w sytuacji, gdy wróg znajdował się bardzo blisko ${ }^{10}$. Należało wówczas

[...] bez omieszkania wszelakiego osobę jaką sprawną a mądrą z huf$\mathrm{cu}$, gdzie renfan postawion będzie [czyli z oddziału szancmistrza - K.Ł.], wprzód posłał, żeby sposób ciągnienia nieprzyjacielskiego, w jakim ordunku a szykowaniu są a jaką sprawą a mocą ciągną i jakim porządkiem postępują, dobrze a roztropnie rozpowiedzieć a wszystkich rzeczy im potrzebną sprawę jako się co dzieje, dać ma a ich dalej nauczać a rozumnie im przepowiedać, jako przeciwko nim dalej postępować mają ${ }^{11}$.

Co więcej, ludzie znajdujący się pod renfanem powinni obserwować przyszłe pole bitwy, aby wykryć ukrytych wrogów lub przygotowane pułapki ${ }^{12}$.

9 T.M. Nowak, Uwagi o technice budowy mostów..., s. 368-371. Stanisław Sarnicki (Księgi hetmańskie, oprac. M. Ferenc, Kraków 2015, s. 195) wymienia już „laskę Jakubową” jako jedno z urządzeń, które zawsze powinny znajdować się w taborze wojskowym.

${ }^{10}$ Książę pruski zwraca uwagę, że naczelny wódz nie powinien podejmować żadnych działań w przypadku bliskości wojsk nieprzyjacielskich, dopóki nie dokona rozeznania, „aże pierwej wyrozumie prawą istność przyrodzoną onego miejsca, gdzie się nieprzyjaciel legrować, a położyć chce. Item sposób ziemie, gdzie wojsko swe wiedzie. Item sposób tych miesc, gdzie sam nieprzyjaciel przebywa a mieszka”. Die Kriegsordnung..., s. 166. W oryginale przechowywanym w Bibliotece Książąt Czartoryskich, rkps 1813, fragment ten znajduje się we wstępie na stronach XXXVXXXVI. Odmienna numeracja stron w pracy: S. Alexandrowicz, Rozwój kartografii Wielkiego Księstwa Litewskiego od XV do połowy XVIII wieku, Poznań 1989, s. 182.

${ }^{11}$ Die Kriegsordnung..., s. 236, 238. Wszystkie wyróżnienia w cytatach pochodzą ode mnie.

${ }^{12}$ Zob. ibidem, s. 242-261. 
Książę pruski nie pisze wprost o wykorzystaniu źródeł kartograficznych, choć ich przydatność wydaje się oczywista. Niewątpliwie jednak decydującą rolę odgrywała naoczna ocena sytuacji ${ }^{13}$. Rozwiązania zaproponowane przez Hohenzollerna przetrwały przynajmniej do początków XVIII wieku. Z uwagi na brak opracowań pozwalam sobie przywołać rosyjską regulację Piotra I z 1716 roku. Kiedy generał-kwatermistrz otrzymał rozkazy o wymarszu armii, miał dokonać rozpoznania

[...] dzień wcześniej z silną eskortą kawalerii takowe miejsce, jak jest położone i jakimi bezpiecznymi drogami wojsko może tam maszerować; musi to wszystko przy pomocy sobie podwładnych oficerów na mapie polowej narysować i przedstawić; a przy swoim powrocie poinformować, co przy tym należy wziąć pod uwagę, aby generalicja wcześniej nie tylko położenie miejsca znała, ale i środki swoje w tych sprawach przedsięwziąć mogła ${ }^{14}$.

Zadania przedstawione przez Hohenzollerna uważam za kluczowe do zrozumienia działalności operacyjnej w XVI stuleciu.

Jako pierwszy potrzebę wojskowego wykorzystania map podczas przemarszu armii odnotował Stanisław Łaski w pracy Księgi o gotowości wojennej powstałej w latach 40 . XVI wieku ${ }^{15}$. Autor odnotował potrzebę jak najlepszej orientacji podczas działań wojennych:

${ }^{13}$ Nawet $\mathrm{w}$ drugiej połowie XVIII wieku, kiedy kartografia wojskowa stała na nieporównywalnie wyższym poziomie, uważano, że „kiedy może sam generał ogląać, niech nigdy nie zleca drugim. [...] Generał przezorny potrafi profitować z najmniejszego pagórka, z wąwozu, z wybojów, z błota etc.”. Oczywiście dowódca powinien „najprzód wyuczyć się dobrze mapy prowincyi, w której się wojna toczy”. Myśl o sztuce wojennej [...], w: B. Paprocki, Flawijusza Wegecyjusza Renata męża zacnego o sprawie rycerskiej nauka [...] tłumaczona przez Franciszka Paprockiego [...], t. 1, Łowicz 1776, s. 436-437.

${ }^{14}$ Kodeks wojskowy Piotra I z 1716 roku, oprac. i przeł. P. Krokosz, K. Łopatecki, Kraków-Oświęcim 2016, s. 115. Por. A.L. Oelsnitz, O bagażach wojska w polu będącego, oprac. K. Łopatecki, Oświęcim 2014, s. 157.

${ }_{15}$ S. Alexandrowicz, K. Buczek, Polska kartografia wojskowa do połowy XVII wieku, w: Dzieje polskiej kartografii wojskowej i myśli strategicznej. Materialy z konferencji, oprac. B. Krassowski, J. Madej, Warszawa 1982, s. 10; T. Korzon, Dzieje wojen 
Kto chce co dobrego, a prędkiego udziałać a nieprzyjaciela pożyć, ma być świadom nie tylko położenia ziemi, ale dróg i inszych chodników i ścieżek, gór, przechodów, błot, rzek, przeskoków i ma tę sprawę miewać za wielkim nakładem swym, nie od jednego, aby nie mylił, ale od kilku ich pewnych. I owszem mądrzy hetmani, na pamięć, a pow[i]eść, dać się uwodzić nie mają: co dać, to dać, aby malowane krainy mieć, skąd się czego nadziewać, a czemu kędy zabiegać potrzeba ${ }^{16}$.

Warto podkreślić, że Łaski, podobnie jak Albrecht Hohenzollern, zaakcentował dominującą rolę rozpoznania wojskowego, przewodników i szerzej - osób mających praktyczną wiedzę o okolicznych terenach. Założenia te poświadczają liczne źródła historyczne. Przywołam stosunkowo wczesną relację niemieckiego kronikarza Ludwika Nakera, dotyczącą wyprawy z 1497 roku. Johann von Tieffen, wielki mistrz zakonu krzyżackiego, dowodził wówczas czterystuosobowym oddziałem zmierzającym do Mołdawii. Jego pułk musiał więc przebyć niemal całe Królestwo Polskie oraz Mazowsze. Droga tego oddziału prowadziła w sposób zupełnie przypadkowy aż do Lwowa (trasa nie była odgórnie wyznaczona). W mieście tym jednak

[...] dano mu [...] przewodnika, który go wraz z oddziałem miał prowadzić do obozu królewskiego drogą taką, gdzieby jeszcze poprzednio nie było przeciągało wielu żołnierzy królewskich, gdzieby więc jeszcze znaleźć można pożywienie dla ludzi i koni $^{17}$.

i wojskowości w Polsce. Epoka przedrozbiorowa, t. 1, Kraków 1912, s. 304 (reprint: Poznań 2003); S. Herbst, Potrzeba historii, t. 2, Warszawa 1978, s. 488-489; B. Olszewicz, Wzmianki o znaczeniu map w literaturze Polskiej XVI wieku, „Acta Universitatis Wratislaviensis. Studia Geograficzne" 1 (1963), s. 133; Z. Parucki, Zarys geografii wojennej, Warszawa 1967, s. 42; T. Zarębska, Początki polskiego piśmiennictwa urbanistycznego, Warszawa 1975, s. 231; S. Alexandrowicz, Rozwój kartografii..., s. 160; J. Sikorski, Polskie piśmiennictwo wojskowe od XV do XX wieku, Warszawa 1991, s. 62.

${ }^{16}$ S. Łaski, Stanisława Łaskiego, wojewody sieradzkiego, prace naukowe i dyplomatyczne, wyd. M. Malinowski, Wilno 1864, s. 8.

${ }_{17}$ X. Liske, Cudzoziemcy w Polsce, Lwów 1876, s. 16, jest to przekład z dzieła Nakera: Liborius Naker's Tagebuch, hrsg. M. Toeppen, w: Scriptores Rerum Prussicarum, Bd. 5, Leipzig 1874, s. 295. 
Warto uzupełnić, że kronikarz nie zdawał sobie sprawy, iż kwestie aprowizacyjne wymusiły znaczne wydłużenie trasy. Dziewiętnastowieczny wydawca - Ksawery Liske - konfrontując jej przebieg ze źródłami kartograficznymi, dodaje: „Dlatego to, jak zobaczymy, maszeruje oddział krzyżacki tak krętą drogą" ${ }^{18}$.

Oprócz specjalnych przewodników wykorzystywano wiedzę lokalnych mieszkańców. Na ich przydatność w działaniach operacyjnych zwrócił uwagę Marcin Broniowski. Opisał on wojskowość Tatarów krymskich na podstawie obserwacji poczynionych podczas misji dyplomatycznej w 1579 roku $^{19}$. Według autora Tatarzy uzyskiwali informacje o nieznanym obszarze dzięki relacjom złapanych przez zwiadowców mieszkańców, którzy pod przymusem ujawniali wszelkie informacje topograficzne ${ }^{20}$. Taki sposób pozyskiwania wiedzy był bardzo skuteczny przynajmniej do początków XVIII wieku, kiedy to wykorzystywano go w aspekcie operacyjnym. Przykładowo według regulacji Piotra I z 1716 roku armii powinien towarzyszyć kapitan przewodników. Niezbędne było, aby znał on kilka języków (w tym język używany przez lokalnych mieszkańców). Kapitan z podnajętymi przewodnikami oraz z pomocą okolicznych mieszkańców (w razie problemu przymusowo wcielanych do wojska) powinien wyznaczać trasę armii ${ }^{21}$.

Jak wynika z pracy Łaskiego, już w pierwszej połowie XVI wieku elementem uzupełniającym wiedzę topograficzną miały być źród-

18 X. Liske, Cudzoziemcy w Polsce, s. 16.

19 M. Broniowski, Martini Broniovii, de Biezdzfedea Bis In Tartariam Nomine Stephani Primi Poloniae Regis Legati Tartariae Descriptio, Köln: Officina Birckmannica 1595, s. 19. Źródło to ostatnio zostało przetłumaczone na język polski: M. Broniewski [M. Broniowski], Tartariae descriptio. Opis Tatarii, przel. E. Śnieżewska, wyd. M. Mączyńska, Łódź 2011.

20 M. Broniowski, Martini Broniovii..., s. 19.

${ }^{21}$ Kodeks wojskowy Piotra I..., s. 123-124 (rozdz. XXXI O kapitanie przewodników). Por. J.M.J. Kampenhauzen, Obserwacyje do wojennych operacyj i akcyj, Biblioteka PAN w Kórniku, rkps 659, s. 26; A.L. Oelsnitz, O bagażach wojska..., s. $123-124,160$. 
ła kartograficzne. Autor wskazał pośrednio, jakie elementy powinny być odnotowane na mapie: trakty, sieć hydrologiczna, góry, lasy, bagna oraz wszelkie miejsca, które mogły stanowić pomoc w trasie (mosty, przełęcze, brody itp.). Próżno jednak szukalibyśmy spełniających takie kryteria map drukowanych powstałych nie tylko w XVI, ale nawet i w XVII stuleciu ${ }^{22}$. Autor zwraca uwagę również na porę roku prowadzonej kampanii wojennej. W szczególności niezbędne były informacje dotyczące temperatur, zwłaszcza terminów występowania lodu na rzekach i jeziorach. Tym samym zasygnalizowana została konieczność umieszczania opisów przy publikowanych mapach. Generalnie analizowany fragment stanowi bardziej postulat niż realną możliwość praktycznego wykorzystania map podczas planowania operacyjnego.

Myśl teoretyczna była kontynuowana między innymi przez Andrzeja Frycza Modrzewskiego, który swoją koncepcję przedstawił w wydanym po raz pierwszy w 1551 roku dziele O poprawie Rzeczypospolitej (Commentariorum de republica emendanda libri quinque ${ }^{23}$. Uznał on, że każde państwo przygotowujące się do wojny powinno znać „położenie, i sposób onej krainy, do której się wojna ciągnie, jeśli jest górzysta, czyli równa, co za rzeki, lasy, miasta i zamki ma”. Za wzór w tej materii podał Portę Otomańską, której władca najpierw rozpoznaje

${ }^{22}$ Wyjątkowy charakter (ale też nieuwzględniający wszystkich wymienionych elementów) ma dzieło Stanisława Porębskiego zatytułowane Ducatus Oswieczimen[sis] et Zatoriensis descriptio z 1563 roku (Venetia: Libraria del S. Marco). Zob. J. Pietkiewicz, Mapa księstwa oświęcimskiego i zatorskiego Stanistawa Porębskiego (1563), w: [S. Pietkiewicz, G. Kwiatkowska-Gadomska], Studia nad dokładnościa dawnych map ziem polskich. Trzy mapy z XVI i XVII wieku, Warszawa 1980 (Studia i Materiały do Dziejów Nauki Polskiej. Seria C, z. 24), s. 63-78; S. Alexandrowicz, Najstarsza mapa szczegółowa ziem polskich. Stanisława Porębskiego mapa księstwa oświęcimskiego i zatorskiego z 1563 roku, w: Mente et litteris. O kulturze i społeczeństwie wieków średnich, red. H. Chłopocka et al., Poznań 1984, s. 357-372. Zob. także Zamek Królewski w Warszawie - Muzeum, Kolekcja dr. Tomasza Niewodniczańskiego, sygn. TN 2417 (dep. Deutsch-Polnische Stiftung Kulturpflege und Denkmalschutz).

${ }^{23}$ M. Korolko, Andrzej Frycz Modrzewski: humanista, pisarz, Warszawa 1978, s. 60. 
[...] położenie krainy i miejsce; stara się przez szpiegi albo chrześcijany na to najęte, aby je wymalowane mieli, i nigdy on do nas nie przychodzi, aż wszystko pierwej przewiedziawszy i przepatrzywszy. A stądże wie, gdzie ma wojsko szykować, gdzie bitwę dać a zastawić się $e^{24}$.

Autor nie ograniczył się jedynie do wskazania wykorzystania strategicznego mapy, ale wyraźnie zaakcentował element operacyjny. Modrzewski uznał, że należy wykonywać specjalne mapy rękopiśmienne, które powinny być na tyle szczegółowe, aby możliwe było opracowanie na ich podstawie decyzji operacyjnych - marszruty oddziałów, podejmowania działań o charakterze ofensywnym lub defensywnym.

Autor wskazywał na wzorzec turecki ze względu na działalność takich kartografów jak Piri Reis, który wykonywał bardzo dokładne mapy wysp i ziem położonych nad Morzem Śródziemnym. Mapy te zostały zebrane w księdze zatytułowanej Kitab-ı Bahriye. Wersja z 1526 roku zawierała 290 map, które były wykorzystywane przez turecką flotę i wojsko lądowe ${ }^{25}$. Należy jednak pamiętać, że znaczenie kartografii doceniał już Mehmed II Zdobywca (1444-1446 i 1451-1481), który wykorzystywał tę dyscyplinę wiedzy przy oblężeniu Konstantynopola i podbojach na Peloponezie i Bałkanach. Z kolei z czasów panowania Bajazyda II (1481-1512) znana jest najstarsza zachowana mapa, która przedstawia okolice Kijowa wraz z lokalizacją wsi nad rzekami Dniepr i Dniestr (il. 2) ${ }^{26}$. Na stworzonej wówczas mapie umieszczono informację, że okolice rekognoskował

24 A.F. Modrzewski, O poprawie Rzeczypospolitej księgi czwore, przeł. C. Bazylik, Łosk: J. Karcan, 1577, k. 112-112v. Wersja łacińska: A.F. Modrevii, Commentariorum de republica emendanda libri quinque, Basilea: Johann Oporinus, 1554, s. $163-164$.

25 Wersja elektroniczna Kitab-ı Bahriye: art.thewalters.org/detail/19195 (dostęp: 12.05.2016). Por. S. Soucek, Islamic Charting in the Mediterranean, w: The History of Cartography, vol. 2, book 1: Cartography in the Traditional Islamic and South Asian Societies, ed. by J.B. Harley, D. Woodward, Chicago-London 1992, s. 266-284, 290-292.

26 Topkapı Sarayı Müzesi Arşivi, Istanbul E. 12090/1. 


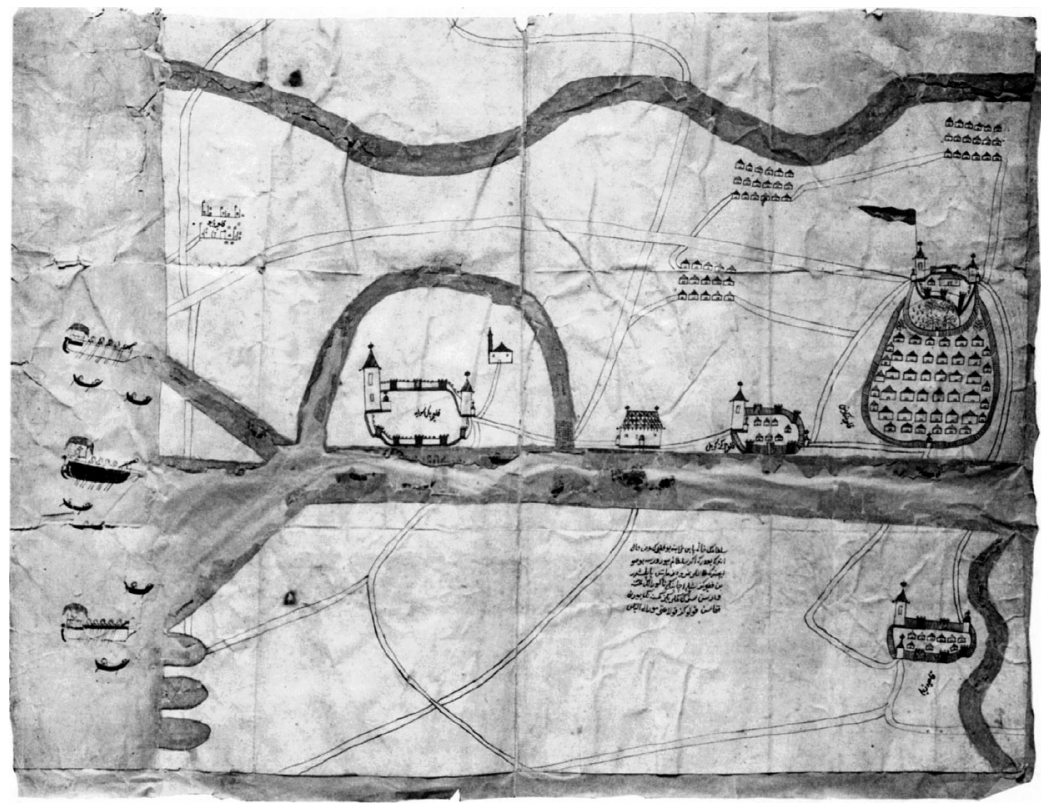

Il. 2. Kijów i okolice, 1495-1506 (Topkapı Sarayı Müzesi Arşivi, Istanbul, E. $12090 / 1)$

Ilyas z Morei. Celem było zdobycie tego miasta z wykorzystaniem osmańskiej floty. Praca wykonana została prawdopodobnie w roku 1497 (ok. 1495-1506)27. Na uwagę zasługuje również doskonały plan Belgradu, którego używano podczas oblężenia miasta w 1521 roku $^{28}$. Warto przywołać postać innego tureckiego kartografia - Matrakçı Nasuha. Służył on w wojsku jako zwiadowca i był prawdopodobnie

${ }_{27}$ Z. Abrahamowicz, Stara turecka mapa Ukrainy z planem wysadzenia dnieprzańskich porohów i ataku floty tureckiej na Kijów, „Studia Historyczne” 44 (2001), nr 1, s. 3-23; D. Kołodziejczyk, The Crimean Khanate and Poland-Lithuania. International Diplomacy on the European Periphery $\left(15^{\text {th }}-18^{\text {th }}\right.$ Century). A Study of Peace Treaties Followed by Annotated Documents, Leiden 2011, s. 27.

${ }_{28}$ A.T. Karamustafa, Military, Administrative, and Scholarly Maps and Plans, w: The History of Cartography, vol. 2, book 1, s. 209 i nn. 
pomysłodawcą naturalistycznych miniatur, na których ukazywał krajobrazy i miasta pozbawione wyobrażeń ludzkich. Dzieła te stanowiły realizację map marszrutowych, a część z nich została skopiowana na potrzeby pisanych w późniejszym okresie prac historycznych. Zachowały się między innymi wykonane przez Nasuha miniatury z pierwszej kampanii irańsko-irackiej (1534-1535) ${ }^{29}$.

Pomysły wyartykułowane przez Stanisława Łaskiego i Andrzeja Frycza Modrzewskiego zostały rozwinięte przez Jana Amora Tarnowskiego w dziele Consilium rationis bellicae, które zostało wydrukowane w roku 1558. Głównodowodzący zobowiązany był do podejmowania działań „dziś, kędy jutro, jakimi miejscy, jeśli górami, jeśli lasy, czyli polami, ciasnymi, czyli przestronymi miejstcy, jeśli rzeki, błota, mosty przebywane będą, a gdzie a jak daleko jutro $\mathrm{z}$ wojskiem ma leżeć" ${ }^{30}$. A zatem dowódca wraz z radą wojenną powinni przynajmniej z dziennym wyprzedzeniem (podobnie jak proponował Albrecht Hohenzollern) planować marszrutę armii, dostosować trasę do warunków hydrogeologicznych i przyrodniczych. Ważnym elementem był wybór miejsca pod obóz na następny dzień.

Oczywiście aż do końca panowania ostatniego Jagiellona szczegółowość map drukowanych nie poprawiła się na tyle, aby można było je wykorzystywać do działań operacyjnych ${ }^{31}$. Dlatego hetman wielki koronny proponował, aby „miał wypisanie wszelakiego przebywania tam, kędy ciągnąc ma, co ma być przed nim na drodze, co też po stronam"32. Fragment ten jednoznacznie wskazuje, że forma ma tu

${ }^{29}$ J.M. Rogers, Itineraries and Town Views in Ottoman Histories, w: The History of Cartography, vol. 2, book 1, s. 230.

${ }^{30}$ J. Tarnowski, Consilium rationis bellicae, Tarnów 1558, k. 10v.; idem, Consilium rationis bellicae, oprac. T.M. Nowak, Warszawa 1987, s. 79; por. S. Alexandrowicz, K. Buczek, Polska kartografia wojskowa..., s. 10.

${ }^{31}$ Zob. S. Alexandrowicz, Kartografia ziem Wielkiego Księstwa Litewskiego w epoce panowania Jagiellonów, „Polski Przegląd Kartograficzny” 46 (2014), nr 1, s. $62-75$.

32 J. Tarnowski, Consilium..., Tarnów 1558, k. 10v.-11; idem, Consilium..., Warszawa 1987, s. 79, 81. 
znaczenie drugorzędne $e^{33}$ - mogła być wykonana zarówno mapa ${ }^{34}$, jak i schematyczny opis drogi (intinerarium) ${ }^{35}$. Podkreślić należy, że itineraria były szczególnie użyteczne w razie ich połączenia $\mathrm{z}$ niedoskonałymi nawet mapami wielkoskalowymi ${ }^{36}$.

Spostrzeżenia dotyczące działalności operacyjnej poczynione przez Tarnowskiego w pełni podziela Marcin Bielski w Sprawie rycerskiej wydanej w 1569 roku $^{37}$. Przywołując wojskowość starożytnych Rzymian, autor zaznacza, że prowadzili oni rozpoznanie tere-

${ }_{33}$ Por. T. Korzon, Dzieje wojen..., t. 1, s. 311; B. Olszewicz, Kartografia polska XV-XVII wieku (przeglad chronologiczno-bibliograficzny), oprac. J. Ostrowski, Warszawa 2004, s. 133; S. Alexandrowicz, Rozwój kartografii..., s. 181.

${ }^{34}$ Pierwsze drukowane mapy dróg zostały wydane około 1500 roku. Są to dwie prace: Erharda Etzlauba Erstausgabe der Romwegkarte oraz Giovanniego Pontana Vera et integra limit. Regni Neapolitani mappa topo. Ferdinandi Regis jussu mensurata [...] studio et opera Joan. Jov. Należy nadmienić, że Etzlaub objął swoją mapą również ziemie śląskie. Zob. B. Englisch, Erhard Etzlaub's Projection and Methods of Mapping, „Imago Mundi” 48 (1996), s. 103-123; L. Bagrow, History of Cartography, New Brunswick-London 2010, s. 93; R. Wytyczak, Śląsk w dawnej kartografii. Obraz Ślaska na mapach XVI-XVIII wieku w zbiorach Zakładu Narodowego im. Ossolińskich we Wrocławiu, Wrocław 1998, s. 18-19.

${ }^{35}$ Szczegółowymi opisami dróg dysponował już na przełomie XIV i XV wieku zakon krzyżacki. Wysyłał on na teren Wielkiego Księstwa Litewskiego szpiegów, którzy następnie opisywali trasy, które mogły być wykorzystane przez wojsko podczas wypraw ofensywnych. Znanych jest ponad sto tak sporządzonych opisów dróg $\mathrm{z}$ lat 1384-1402. Zob. Die Littauischen Wegeberichte, w: Scriptores Rerum Prussicarum, hrsg. von T. Hirsch, M. Töppen, E. Strehlke, Bd. 2, Leipzig 1863, s. 662-708; por. V. Almonaitis, Laukuvos apylinkès kryžiuočiu karo keliu aprašymu duomenimis, w: Laukuva. Lietuvos valsčiai I, Vilnius 2005, s. 171-183. Formę rozbudowanego opisu drogi ma relacja Ludwika Nakera, która przedstawia podróż posiłkowego wojska zakonnego zmierzającego do Mołdawii w 1497 roku. Zob. X. Liske, Cudzoziemcy $w$ Polsce, s. 7-22.

${ }^{36}$ Stanisław Alexandrowicz i Karol Buczek słusznie zauważyli, że itineraria stanowią najstarsze obiekty, które można zaliczyć do zabytków kartografii wojskowej. S. Alexandrowicz, K. Buczek, Polska kartografia wojskowa..., s. 8.

${ }^{37}$ O znaczeniu Sprawy rycerskiej można mówić właściwie tylko do końca XVI wieku, gdyż już w 1604 roku trafiła do Indeksu ksiag zakazanych (Index librorum prohibitorum). I. Chrzanowski, Marcin Bielski. Studyum literackie, Warszawa 1906, s. 271; M. Furman, „Sprawa rycerska” Marcina Bielskiego - staropolski traktat 
nu, które służyło za podstawę przy podejmowaniu bieżących działań operacyjnych. Również u Bielskiego rozpoznanie powinno być robione z jednodniowym wyprzedzeniem, przy czym winno ono mieć szerszy zakres niż u Tarnowskiego. Bielski wymienia konieczność rozpoznania wojsk nieprzyjaciela (w Consilium tego nie podano, co raczej należy rozumieć jako pominięcie rzeczy oczywistej), ustalenia miejsc przeprawy przez rzeki, położenia bagien, gór i lasów ${ }^{38}$.

Marcin Bielski, mimo że nie odwołuje się bezpośrednio do kartografii, może być uznany za pierwszego, który na ziemiach polskich przybliżył istotę wykonania map marszrutowych ${ }^{39}$. Podstawowa trudność w sporządzeniu planów okolic tras przemarszu armii dotyczyła czasu i okoliczności - wykorzystanie instrumentów kartograficznych wymagało żmudnych przygotowań, a postępy były powolne ${ }^{40}$. Konieczne było zastosowanie rozwiązań, które pozwoliłyby wykonać prowizoryczny szkic terenowy podczas przemarszu armii. Oczywistym sposobem było mierzenie odległości przez liczenie kroków.

czy podręcznik wojskowy?, w: Studia nad staropolska sztuka wojenna, t. 2, red. Z. Hundert, Oświęcim 2013, s. 37-39.

${ }_{38}$ M. Bielski, Sprawa rycerska według postępku i zachowania starego obyczaju rzymskiego, greckiego, macedońskiego i innych narodow pierwszego $i$ niniejszego wieku tak pogańska jako i krześcijańska z rozmaitych ksiag wypisana ku czytaniu i nauce luddziom rycerskim pożyteczna, Kraków: Mateusz Siebeneicher, 1569, k. 7; idem, Sprawa rycerska, w: Archiwum domowe do dziejów literatury krajowej, wyd. K.W. Wójcicki, Warszawa 1856, s. 290. Por. M. Furman, „Sprawa rycerska” Marcina Bielskiego..., s. 45-46, 58.

39 Szerzej o mapach marszrutowych zob.: K. Lopatecki, Prace kartograficzne wykonane na ziemiach Rzeczypospolitej przez szwedzkich inżynierów wojskowych w XVII stuleciu, „Studia i Materiały do Historii Wojskowości” 46 (2009), s. 71-75; T.M. Nowak, Szwedzkie źródło kartograficzne ukazujące trasę przemarszu armii M.G. de la Gardie ze Żmudzi na Mazowsze w 1655 r., „Studia i Materiały do Historii Wojskowości” 30 (1988), s. 321-328; K. Łopatecki, W. Walczak, Mapy i plany Rzeczypospolitej XVII w. znajdujące się $w$ archiwach $w$ Sztokholmie. Maps and Plans of the Polish Commonwealth of the 17th c. in Archives in Stockholm, t. 1, Warszawa 2011, s. 242-289.

40 Przegląd metod, których używali kartografowie w XVI stuleciu, zob. P. Pfinzing, Methodus geometrica, Nürnberg 1598, k. 1-45. 
Jak pisze autor Sprawy rycerskiej, armia rzymska robiła w ciągu dnia 20004 kroki wielkie. Ta dziwna liczba stanowi oczywiście błąd zecerski, tym bardziej że w dalszej części tekstu podana jest poprawna, zaokrąglona wartość ${ }^{41}$. Istotniejsze jest wyjaśnienie pojęcia „krok wielki”. Był to krok podwójny, odpowiednik starorzymskiego określenia passus. Tysiąc takich kroków równało się mili rzymskiej (następnie była to odległość zbliżona do mili niemieckiej) ${ }^{42}$. Przez pojęcie kroku podwójnego Marcin Bielski rozumiał odległość $148 \mathrm{~cm}$, a zatem krok zwykły (gradus) liczył $74 \mathrm{~cm}$. Ten drugi wymiar utrzymał się w niezmienionej postaci przez cały okres nowożytny. Jeszcze 221 lat później podana jednostka kroku wojskowego była niemal identyczna i wynosiła $75 \mathrm{~cm}^{43}$. A zatem według Bielskiego wojsko przez 5 godzin marszu wykonywało 20000 kroków podwójnych, co oznacza, że przemieszczano się z prędkością niemal $6 \mathrm{~km}$ na godzinę $(5,92 \mathrm{~km} / \mathrm{h})^{44}$.

${ }^{41}$ M. Bielski, Sprawa rycerska..., 1569, k. 6v., 10.

42 Ibidem, k. 6v.-7; T. Bogacz, Wiedza geograficzna o Śląsku $w$ dobie odrodzenia, Wrocław 1990, s. 34; T. Zagrodzki, Regularny plan miasta średniowiecznego a limitacja miernicza, Wrocław 1962, s. 41.

43 „Pod nazwiskiem ludzkich krokow, nie trzeba brać tak nazwanych geometrycznych krokow, 5 stop długości maiących [...] lecz takie poiedyncze kroki, które człowiek bez naymnieyszego przymusu czyni zazwyczay. Te wprawdzie u każdego prawie człowieka względem wielkości różnią się nieco, biorą się iednak zwyczayn[i]e po $2 \frac{1}{2} 2$ warszawskich stop: że więc 10 stop uczyni 4 kroki”. P. Hogrewe, Teoryczna i praktyczna nauka żołnierskich rozmiarów, czyli miernictwo wojenne do użycia oficyjerom i początkowym inżenierom, przeł. J. Łęski, Warszawa: Piotr Dufour, 1790, s. 182-183. Na kolejnych stronach znajduje się wiele praktycznych rad związanych $\mathrm{z}$ rekognoskowaniem.

44 Jest to tempo bardzo szybkie, robione w XIX stuleciu doświadczenia pokazały, że przeciętna długość kroku wynosiła $81 \mathrm{~cm}$, a średnie tempo marszu wahało się od 4,5 do $5,5 \mathrm{~km}$ na godzinę (średnio 5). Akcentowano, że dłuższy marsz o szybkości powyżej 5,5 km na godzinę nie jest możliwy. „Dwutygodnik Medycyny Publicznej. Organ Towarzystwa lekarzy galicyjskich” 1 (1877), nr 1, s. 140. W innych badaniach zauważono, że człowiek przemieszcza się z prędkością 125 kroków na minutę, co w skali godziny daje 7500 kroków pojedynczych (według M. Bielskiego 8000). [P. Dupin], O fizyczney sile człowieka, i iey użyciu pod względem przemysłowym, „Izys Polska czyli Dziennik umiejętności, wynalazków, kunsztów i rękodzieł” 
Marcin Bielski po raz pierwszy na terenie Rzeczypospolitej przedstawia proste i skuteczne założenie, że odległości można mierzyć za pomocą kroków ${ }^{45}$. Wykorzystuje przy tym dorobek Flaviusa Vegetiusa Renatusa, zawarty w rozdziale dziewiątym księgi pierwszej De re militari ${ }^{46}$. Znając tempo marszu, można ocenić, jaki odcinek drogi został przemierzony po upływie określonego czasu. Korelacja, jak się wydaje, była dla współczesnych stosunkowo oczywista $^{47}$. Wiemy, że siedemnastowieczni inżynierowie wojskowi, którzy rekognoskowali przed armią teren, również z reguły nie używali specjalnych urządzeń (z wyjątkiem busoli), za podstawę pomiarów służyły im kroki ${ }^{48}$. Pierwszy polski wojskowy podręcznik kartograficzny z 1790 roku nie wprowadzał w tej materii znaczących zmian ${ }^{49}$.

Trzeba przy tym zaznaczyć, że w XVI stuleciu na potrzeby kartografów (inżynierów) wojskowych przygotowywano narzędzia ułatwiające

1 (1827), cz. 1, s. 2-3. Doświadczenia przeprowadzane w XIX wieku mają tę zaletę, że uwzględniają przeciętnie niższy niż obecnie wzrost ludzi, także ówczesny stan dróg był bardziej zbliżony do okresu wczesnonowożytnego niż obecny.

${ }_{45}$ Wykorzystanie kroków przez armię w sytuacjach ekstremalnych stosowano jeszcze podczas II wojny światowej. Zob. S. Kopański, Urywki z pamiętnika, w: Samodzielna Brygada Strzelców Karpackich. Opracowanie zbiorowe żotnierzy SBSK, Warszawa 2014, s. 24.

${ }^{46}$ F. Vegetius Renatus, Abriß des Militärwesens: lateinisch und deutsch, mit Einl., Erl. und Indices von F.L. Müller, Stuttgart 1997, s. 42-43; F. Wegecjusz Renatus, Zarys wojskowości ksiag cztery, oprac. i przeł. A.M. Komornicka, „Meander” 28 (1973), nr 10, s. 408.

${ }^{47}$ Przykładowo w Niemczech powszechnie przyjmowano odległość mili jako trasę, którą człowiek przechodzi w ciągu godziny. [P. Dupin], O fizyczney sile..., cz. 1, s. 2-3.

${ }_{48}$ T.M. Nowak, Szwedzkie źródło kartograficzne..., s. 325, 88, 192. Z kolei Wilhelm Beauplan liczył kroki końskie. Zob. S. Pietkiewicz, [Dyskusja], w: Dzieje polskiej kartografii wojskowej..., s. 161.

49 „W wymiarach podczas woyny, nie używa się nigdy mierniczego łańcucha ani mierniczych sznurow; ale raczey mierzy się i rysuie wszystko ludzkiemi a bardziey ieszcze końskiemi krokami”. P. Hogrewe, Teoryczna i praktyczna nauka..., s. 182. 

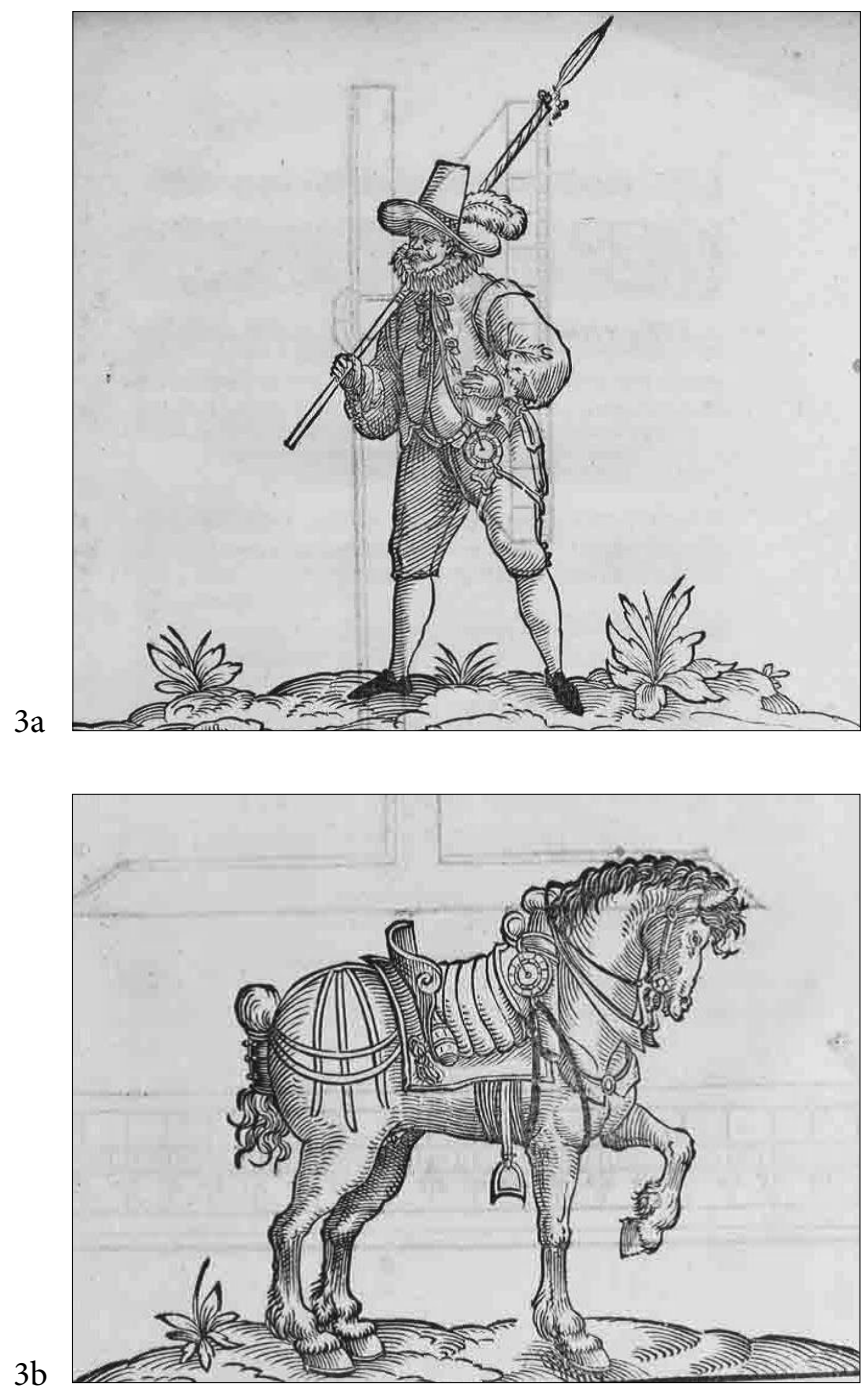

Il. 3a, 3b. Kartograf wojskowy wykorzystujący narzędzie (pedometr) do liczenia kroków (a); pedometr koński (b) (P. Pfinzing, Methodus geometrica, Nürnberg 1598, k. XLv.) 
liczenie kroków własnych lub wierzchowca (il. 3a i 3b) ${ }^{50}$. Niestety, informacji o wykorzystaniu pedometru (Schritttzähler) w XVI wieku na ziemiach polskich brak. Jego zastosowanie pozwoliłoby na doprecyzowanie obliczeń odległości, subiektywne uczucie powodowało bowiem, że na złych drogach wyliczana długość mili miała niską wartość, ta zaś zwiększała się wraz z poprawą jakości traktu ${ }^{51}$.

Szesnastowieczni twórcy, pisząc swoje dzieła, używali typowych miar odległości, przede wszystkim stosowali pojęcie mili. Kiedy jednak narracja dotyczy działań wojennych, bardzo często pojawia się pojęcie kroku. Twórcą, u którego możemy odnaleźć tę zależność, jest między innymi Reinhold Heidenstein, który opisując poczynania wojenne Stefana Batorego, odnotowuje odległości w krokach - pisze przykładowo: „Wilno zaś, odległe stąd [od Połocka - K.t.] było na 225000 kroków” ${ }^{\prime 2}$.

Czy zatem twórcy szesnastowieczni przez pojęcie „krok” rozumieli odcinek zwykły czy też podwójny (passus)? Powyższy cytat może pomóc w odpowiedzi na to pytanie. Pomiędzy Wilnem a Połockiem odległość w linii prostej wynosi $241 \mathrm{~km}$, a najkrótsza obecnie działająca droga utwardzana ma długość $254 \mathrm{~km}$. Tę drugą wartość należy przyjąć jako minimalną w rzeczywistości szesnastowiecznej (zapewne znacznie zaniżoną). Jeżeli przemnożymy 225000 przez $0,74 \mathrm{~m}$, otrzymamy zaledwie $166,5 \mathrm{~km}$, skala błędu jest więc tak duża, że o niedoskonałościach pomiarowych nie może być mowy. Tymczasem przyjęcie hipotezy „kroku podwójnego” w kro-

${ }^{50}$ P. Pfinzing, Methodus geometrica, k. XLv.; H. Minow, Historische Vermessungsinstrumente. Ein Verzeichnis der Sammlungen in Europa, Wiesbaden 1990, s. 201-202.

${ }^{51}$ K. Łopatecki, Wyprawa zbrojna Krzysztofa Radziwiłła „Pioruna” w Inflantach zima 1579 roku, „Zapiski Historyczne” 83 (2018), z. 1, s. 42-47, 61.

${ }_{52}$ R. Heidenstein, Dzieje Polski od śmierci Zygmunta Augusta do roku 1594. Ksiag XII, t. 1, przeł. M. Gliszczyński, Petersburg 1857, s. 317. Inne przykłady: ibidem, s. 310, 311, 318; ibidem, t. 2, s. 6, 13, 15, 16, 17, 28, 31, 63, 64, 66, 74, 76, 82. Sądzę, że Heidenstein miał wiarygodne dane, dzieło zredagowane zostało już po wojnach batoriańskich, w czasie których wielokrotnie przebywano podaną trasę. 
nice oznacza, że podana odległość wynosi $333 \mathrm{~km}$, co biorąc pod uwagę ówczesny stan dróg, wydaje się możliwym rozwiązaniem (jest to trasa dłuższa o 31,1 procent). Przynajmniej zatem odnośnie do drugiej połowy XVI i pierwszej XVII stulecia należy ostrożnie podchodzić do odległości podanej w krokach - może ona mieć zgoła różne znaczenie: 0,74 m lub 1,48 m. Sądzę zatem, że Marcin Bielski, przywołując łaciński podział na kroki wielkie i zwykłe, mógł doprowadzić do zamieszania terminologicznego.

Co więcej, Heidenstein, opisując kampanię 1580 roku, używa ewidentnie miar powstałych na potrzeby kartografów.

W przeciągu jednego dnia przebyto drogę na przestrzeni 20,000 kroków [to jest liczba podana przez Bielskiego! - K.Ł.], wojsko dostało się pod Werszowin, gdzie dawniej wieś była, odległa od Wieliża także na 20,000 kroków [po raz kolejny odległość odnotowana przez Bielskiego - K.Ł.] ${ }^{53}$.

Dodać należy, że kronikarz podaje odległości w krokach wyłącznie podczas opisu kampanii wojskowych.

Pierwszym autorem, który wyraził konieczność zaangażowania specjalnej osoby zajmującej się kartografią wojskową, był Bartosz $\mathrm{Pa}$ procki. W rozdziale XVII O świadomości miejsc i krajów wszelakich z dzieła Hetman albo własny konterfekt hetmański z 1578 roku autor wskazywał na potrzebę wykorzystania na wojnie uczonych, w tym geografów. Oczywiście pomysł był kontrowersyjny. W wojsku dominowało (zresztą nie tylko w tym okresie) nieukrywane lekceważenie teoretyków wojskowości. Zjawisko to uzewnętrznił w swojej pracy Albrecht Hohenzollern, pisząc o „księgowym waleczniku” - co było pogardliwym określeniem osoby, „która jakie księgi w rzeczach rycerskich i inszych czytał, a z nich z inszemi żołnierzami rozmawiał"54.

Niestety Bartosz Paprocki nie napisał wprost, w jakim obszarze działań wojennych widzi praktyczne możliwości wykorzystania umiejętności wspomnianych uczonych. Pośrednio jednak autor wskazuje

53 Ibidem, t. 1, s. 12-13.

54 Die Kriegsordnung..., s. 166. 
interesującą nas funkcję, gdyż za wzór godny naśladowania uznaje cesarza Karola V Habsburga. Władca ten „kędy walczyć miał, na przód wszystkich onych miejsc położenia malowanie widzieć chciał" ${ }^{5}$. Wzór cesarza miłośnika kartografii był w Koronie ugruntowany ${ }^{56}$. Z 1558 roku pochodzi bowiem mowa profesora Akademii Krakowskiej Andrzeja Gostyńskiego, w której ten odwoływał się do działań cesarza. Miał on mieć „na małej mapie dokładnie wymierzone i namalowane wszystkie okolice, miasta, góry, rzeki i lasy”, z którego to źródła często korzystał, co powodowało, że „sam najdogodniejsze miejsca zajmując, a nieprzyjacielowi niewygodne zostawiając, torował sobie drogę do zwycięstwa"57. Prawdopodobnie opinia ta miała swoją genezę w relacji francuskiego pamiętnikarza Martina Du Bellay, który opisując w 1536 roku wizytę u Karola V podczas wojny z Francją, odnotował entuzjastyczny stosunek monarchy do map wykorzystywanych w bieżących działaniach operacyjnych ${ }^{58}$.

A zatem - według Paprockiego - geograf powinien nie tylko znać się na źródłach kartograficznych, ale i posiadać niezbędną wiedzę do wykonywania nowych lub modyfikowania dotychczasowych map. To założenie potwierdza Stanisław Sarnicki, który kumuluje cały poprzedni dorobek w zakresie kartografii wojennej. Zagadnienie to poruszył w rękopiśmiennym dziele Księgi hetmańskie (1577-1580) ${ }^{59}$. Milczy on o wojskowym wykorzystaniu map drukowanych, co wska-

${ }_{55}$ B. Paprocki, Hetman albo własny konterfekt hetmański, Kraków: Mateusz Siebeneicher, 1578, k. E ; idem, Hetman, wyd. K.J. Turowski, Sanok 1856, s. 26.

${ }^{56}$ Szerzej o kartografii austriackiej linii Habsburgów: J. Vann, Mapping Under the Austrian Habsburgs, w: Monarchs, Ministers and Maps. The Emergence of Cartography as a Tool of Government in Early Modern Europe, ed. by D. Buisseret, Chicago-London 1992, s. 153-162.

57 Wybór pism pedagogicznych Polski doby Odrodzenia, wyd. J. Skoczek, Wrocław 1956, s. 242; por. B. Olszewicz, Kartografia polska..., s. 134-135.

${ }^{58}$ M. Du Bellay, Les memoires, Paris: P. L’huillier, 1569, s. 193; J. Vann, Mapping..., s. 158.

${ }^{59}$ M. Ferenc, Wstęp, w: S. Sarnicki, Księgi hetmańskie, s. XIV. 
zuje, że nie widzi ich praktycznej przydatności. Umieszcza natomiast pośród rzemieślników niezbędnych w armii malarza (używa terminu pictor ${ }^{60}$. Jego obecność uzasadnia słowami:

[...] nie dlia maliowania chorągwi, drzewców malarza trzeba ${ }^{61}$, mała to jest rzecz, alie gdy ciągnie wojsko przez niewiadome miesca, aby maliował situm loci onego kraju, drogę, góry, liasy, debrzy [doliny - K.Ł.], rzeki, stawy, błota, wsi, zamki, uchody, przechody in summa wszytkie i ścieżki na koniec, gdzie są i gdzie by mogły byćc ${ }^{2}$.

Rękopiśmienne prace kartograficzne pozwalały dowódcy widzieć „te wszystkie rzeczy przed oczema [...] i może snadnie pojąć jako gdzie okazyją wziąć, których rzeczy ma używać i których fortelów"63. W przytoczonym fragmencie autor wyraźnie zaznacza, że mapy okolicy, w której znajdowało się wojsko, stanowiły ogromną pomoc przy podejmowaniu działań operacyjnych.

Z okresu poprzedzającego panowanie Stefana Batorego nie zachowała się żadna polska lub litewska mapa operacyjna ${ }^{64}$. Informacja

${ }^{60}$ Jest to najstarszy znany przypadek ( $\mathrm{z}$ wyjątkiem niedoprecyzowanego terminu "geograf” odnotowanego przez Bartosza Paprockiego) wyartykułowanej potrzeby posiadania w wojsku kartografa wojskowego. W szczególności hetman Jan Tarnowski i książę pruski Albrecht Hohenzollern, opisując urzędników i zawody towarzyszące armii, pomijają to stanowisko. J. Tarnowski, Consilium..., Warszawa 1987, s. 45-51; Die Kriegsordnung..., s. 218-219.

${ }^{61}$ O wykonywaniu i malowaniu kopii husarskich zob.: Z. Bocheński, „Złote pióra” na kopiach husarskich, „Barwa i Broń” 6 (1939), nr 5-6, s. 71-75; M. Gębarowicz, Niektóre zagadnienia metodologii historii sztuki (cz. II), „Biuletyn Historii Sztuki” 38 (1976), nr 4, s. 334-339.

${ }^{62}$ S. Sarnicki, Księgi hetmańskie, s. 136. Cytuje ten fragment K. Buczek, Kartografia polska w czasach Stefana Batorego, „Wiadomości Służby Geograficznej” 7 (1933), z. 2, s. 103.

63 S. Sarnicki, Ksiegi hetmańskie, s. 136.

${ }^{64}$ Tadeusz M. Nowak przyjął, że właściwa skala w mapach na potrzeby działań operacyjnych wynosić powinna od 1 : 200000 do 1 : 600 000. T.M. Nowak, Polska artyleria, inżynieria i kartografia wojskowa XVII w. - teoria i praktyka, „Studia i Materiały do Historii Wojskowości” 22 (1979), s. 117. Należy podkreślić, że szerokie spektrum działań operacyjnych upoważnia do twierdzenia, że skale mogły 
o najstarszym źródle kartograficznym mającym walory operacyjne pochodzi z pracy Stanisława Sarnickiego. Autor ten umieścił mapę (którą prawdopodobnie skopiował) $\mathrm{w}$ jednej $\mathrm{z}$ ocalonych wersji Ksiag hetmańskich. Niestety mapa ta zaginęła, lecz jej układ przestrzenny znany jest z zachowanej legendy do tego źródła. Obszar na mapie obejmował przynajmniej $35 \mathrm{~km}$ dolnego biegu Wisły. Wiadomo, że na planie odnotowano położenie trzech miast (Gdańska, Pruszcza Gdańskiego i Tczewa), a także wsi Lubieszowo Tczewskie. Nie tylko zaznaczono układ hydrologiczno-urbanistyczny, lecz także wskazano dwa wykonane mosty - jeden polski, drugi gdański, odnotowano również bitwę pod Lubieszowem z 17 kwietnia 1577 roku $^{65}$.

Działania wojenne przeciwko Gdańskowi (1576-1577) to przełom w zastosowaniu kartografii. Świadczą o tym liczne egzemplarze źródeł kartograficznych, które nie ograniczały się jedynie do przedstawienia samego miasta, lecz uwzględniały większą powierzchnię, na której znajdowały się umocnienia i obozy wojskowe. Mapa okolic Gdańska, ujścia Wisły z uwzględnieniem twierdzy Latarni została wykonana (a raczej odpisana) przez ambasadorów saskiego elektora Augusta Wettina. Dzieło Abrahama von Bocka i Andreasa Paulego niestety również się nie zachowało ${ }^{66}$. Więcej szczęścia miała mapa przygotowana 17 września 1577 roku przez Ferdynanda von Schönaicha. Przedstawia ona w rzucie izometrycznym położenie Gdańska i Latarni, obozów wojskowych i armii polowych na tle sieci rzecznej w delcie Wisły (il. 4) ${ }^{67}$. Ponadto w Bibliotece PAN w Gdańsku prze-

być znacznie mniejsze. Na przykład siedemnastowieczne mapy marszrutowe uwzględniające rozmieszczenie oddziałów na kwaterach miały skalę 1: 130000 . Zob. K. Łopatecki, W. Walczak, Mapy i plany..., s. 266-307.

${ }^{65}$ S. Sarnicki, Księgi hetmańskie, s. 479.

${ }^{66}$ W. Behring, Beiträge zur Geschichte des Jahres 1577. II.: Die Berichte der kursächsischen Gesandten Abraham von Bock und Dr. Andreas Pauli über die Friedensvermittlung zwischen König Stephan Bathory und der Stadt Danzig, „Zeitschrift des Westpreussischen Geschichtsvereins" (Danzig) (1903), H. 45, s. 111-112.

${ }^{67}$ Ibidem, po s. 112; T. Korzon, Dzieje wojen..., t. 2, s. 20 i ryc. 16. 
chowywany jest plan o znaczeniu taktycznym, na którym zaprezentowano próbę zdobycia przez siły polskie Latarni ${ }^{68}$.

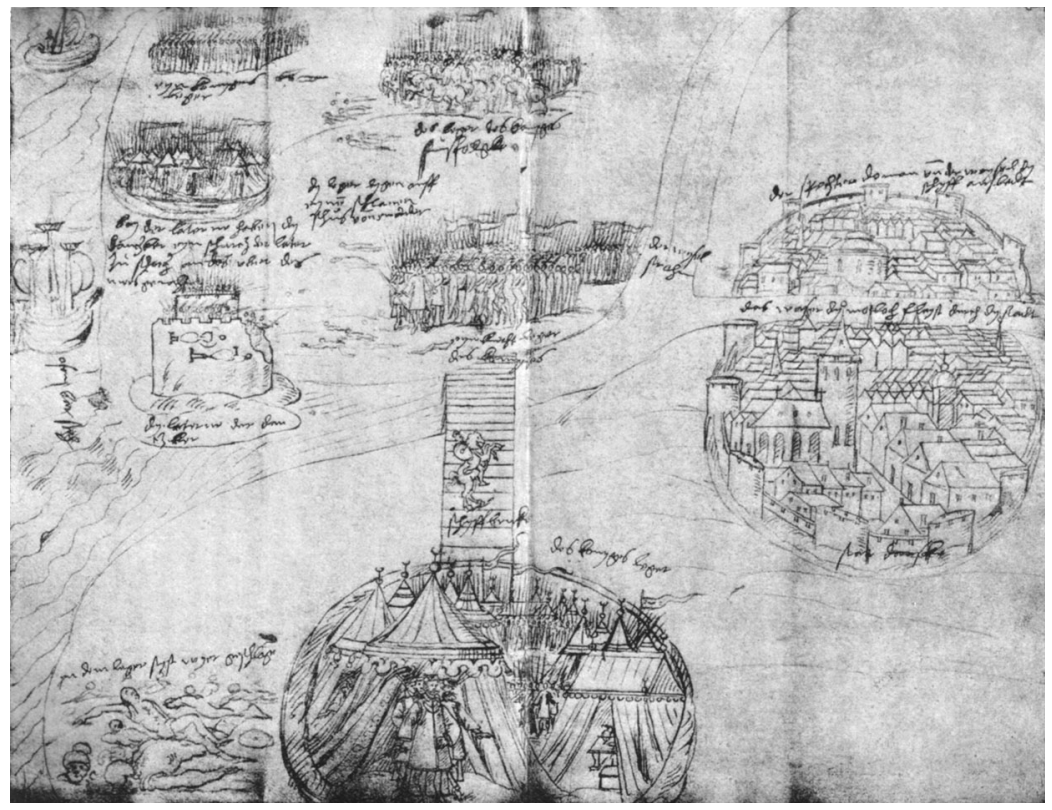

Il. 4. Rozłożenie sił gdańskich i koronnych w 1577 roku (W. Behring, Beiträge zur Geschichte des Jahres 1577. II.: Die Berichte der kursächsischen Gesandten Abraham von Bock und Dr. Andreas Pauli über die Friedensvermittlung zwischen König Stephan Bathory und der Stadt Danzig, „Zeitschrift des Westpreussischen Geschichtsvereins" (Danzig) (1903), H. 45, po s. 112)

${ }^{68}$ Biblioteka PAN w Gdańsku, nr inw. 5664. Analiza tego wyjątkowego zabytku kartografii wojskowej wymaga odrębnego studium. 
Świadectwa o czterech różnych mapach wskazują, że obie strony tego konfliktu wykorzystywały kartografię do planowania operacyjnego i taktycznego. Konflikt ten ma szczególne znaczenie dla kartografii polskiej, gdyż ukazuje przełom w prezentacji działań manewrowych: planowania założenia obozów, budowy mostów, trasy przemarszu armii, przy dostosowaniu się do istniejących fortyfikacji i warunków naturalnych (rzek). Zachowana mapa Schönaicha jest daleka od doskonałości, pozbawiona jest również skali. Orientację mapy (wschodnią - południowo-wschodnią) wyraźnie jednak wyznacza wybrzeże morskie i uchodząca do Zatoki Gdańskiej Leniwka (odnoga Wisły, obecnie Martwa Wisła). Ocena wiarygodności źródła jest o tyle trudna, że miasto Gdańsk, rozbudowując pod koniec XVI, a przede wszystkim na początku XVII wieku fortyfikacje bastionowe, znacznie ingerowało w kształt delty Wisły. Szczęśliwie zachował się profesjonalnie wykonany plan, ukazujący stan fortyfikacji i otoczenia Gdańska z roku 1600 (il. 5) ${ }^{69}$. Jego zestawienie z mapą wcześniejszą o 23 lata dowodzi, że źródło niemieckie było wiarygodne. Oczywiście kształt fortyfikacji miejskich był umowny - zaznaczono jednak Motławę rozdzielającą Gdańsk na dwie części. Generalnie układ hydrologiczny został nieco uproszczony, ale nie prowadziło to do błędnej oceny militarnej sytuacji. Wskazówki podane w legendzie u Stanisława Sarnickiego mogą świadczyć o tym, że mapa wykorzystywana przez stronę koronną była znacznie bardziej użyteczna. Niestety nie da się tego w sposób jednoznaczny udowodnić.

${ }^{69}$ Krigsarkivet, Stockholm, Utländska stads- och fästningsplaner (nr zespołu 406), Tyskland (nr serii 25), Danzig (nr jednostki 44), k. 1. 


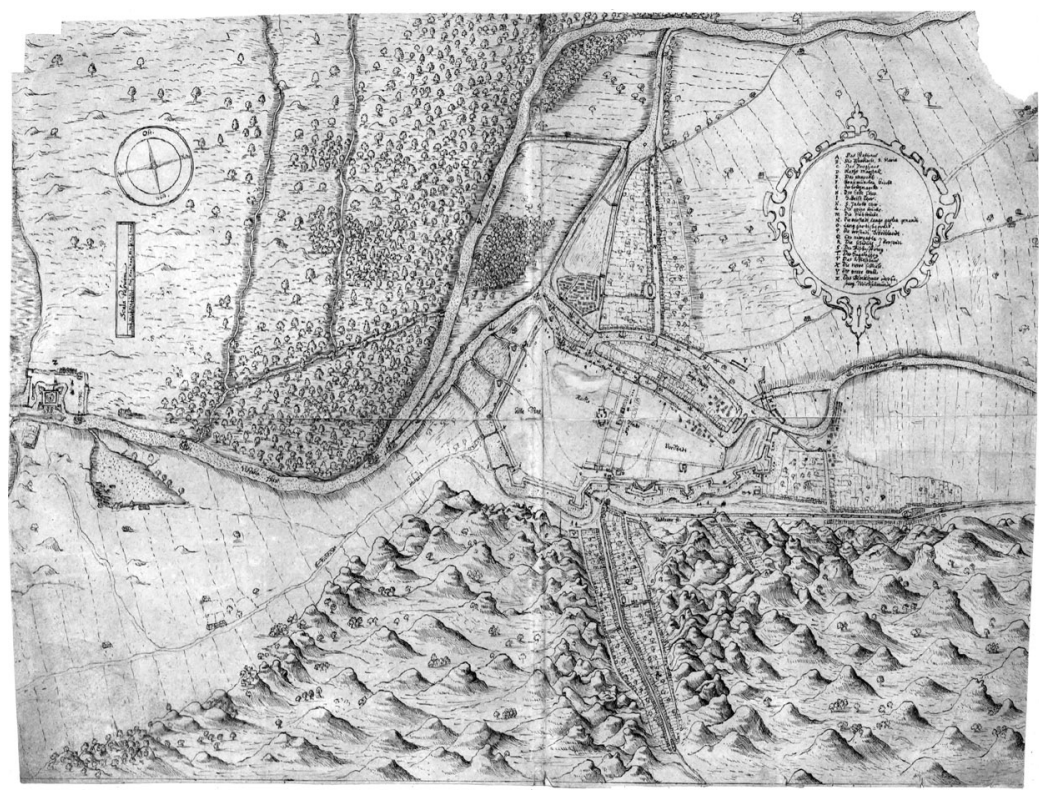

Il. 5. Mapa Gdańska i okolic z 1600 roku (Krigsarkivet, Stockholm, Utländska stads- och fästningsplaner ( $\mathrm{nr}$ zespołu 406), Tyskland (nr serii 25), Danzig (nr jednostki 44), k. 1).

Rozwój kartografii wojskowej w ujęciu operacyjnym poprzedzały opisy dróg (itineraria). To one świadczą o kształtującej się świadomości przestrzennej wśród dowództwa polsko-litewskiego. Niestety z okresu przedbatoriańskiego zachowało się niewiele przykładów zastosowania tego typu opracowań w działaniach wojskowych. Wyjątkowe znaczenie ma źródło Wiadomość kędy w ziemię nieprzyjacielską iść, które wykonano na potrzeby wojsk litewskich około roku 1570 (il. 6). Opisuje ono drogę prowadzącą z Wenden (Kiesi) przez Smiltyń, Kierepeć, Nowy Horodek do Wałek i Ikskul, a następnie szlak powrotny przez Kermissę, Burtniki, Pirkieł, Salę do Dyjamen- 
$\mathrm{tu}^{70}$. Źródło wbrew tezie powtarzanej w literaturze nie jest jednak ogólnikowe $^{71}$. Faktycznie brakuje w dokumencie odległości pomiędzy punktami, za to droga uwzględnia uwarunkowania terenowe (lasy, brzeg morski itp.).

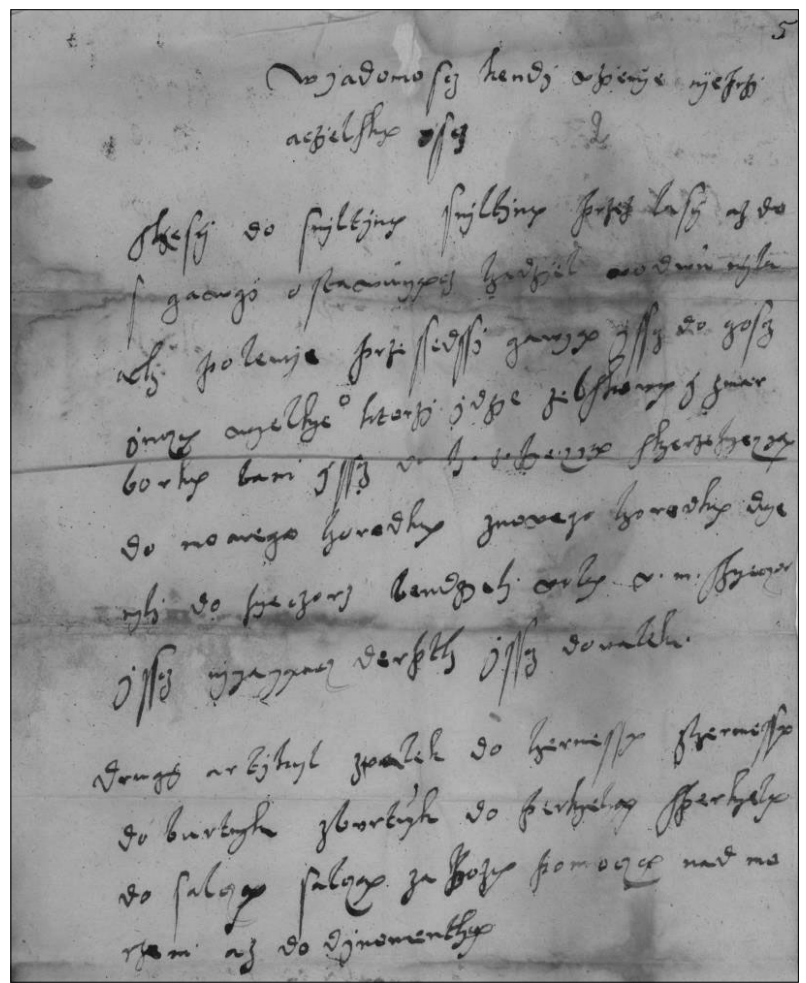

Il. 6. Opis drogi po ziemiach inflanckich z 1570 roku (Российская национальная библиотека, Санкт-Петербург, Ф. 971, Авт. 321/1, № 2, k. 5)

${ }^{70}$ Российская национальная библиотека, Санкт-Петербург, Ф. 971, Авт. 321/1, № 2, k. 5-5v.

${ }^{71}$ S. Alexandrowicz, Rozwój kartografii..., s. 192. 
Niewątpliwie kryterium użyteczności doprowadziło do dominacji map drożnych nad źródłami narracyjnymi ${ }^{72}$. Itineraria stanowiły etap w wykształceniu się map o charakterze operacyjnym ${ }^{73}$. Kluczowe pytanie dotyczy tego, czy Korona i Wielkie Księstwo Litewskie miały możliwości stworzenia odpowiednio szczegółowych map o znaczeniu operacyjnym.

Aby zweryfikować powyższą hipotezę badawczą, należy przypomnieć pracujących $\mathrm{w}$ strukturach cywilnych mierników. Jeszcze w pierwszej połowie XVI wieku osób dobrze wykształconych w tym fachu było niewiele, o czym pisał Stanisław Grzepski. Podkreślał on, że zawód ten upowszechnił się jedynie na Mazowszu ${ }^{74}$, „Bo w Polszcze trudno się miernika dopytać, jam tylko o jednym słyszał na Podgórzu, ale i ten już był umarł"75. W konsekwencji kiedy rozpoczęto w Wielkim Księstwie Litewskim zakrojony na dużą skalę projekt pomiary włócznej, zatrudniano ludzi bardzo słabo wyszko-

${ }^{72}$ W połowie XVII wieku Józef Naronowicz-Naroński informował, że przy zakładaniu obozu z wyprzedzeniem „ma bydź z oboźnym wojskowym indzienier wyprawiony albo i kilka ich, którzy tak położenia miejsca, jako i wczesności wszelakiej nie tylko upatrować, ale i delineacyją tego wszytkiego miejsca na mappie uczynić mają. Potem zniozszy się z hetmanem albo z panem tego wojska, na tej mappie porządną delineacyją stanowienia obozów i jej obronę ma uczynić, według której mappy łacno w polu obóz będzie stanowić i zawierać". J. Naronowicz-Naroński, Budownictwo wojenne, wyd. J. Nowakowa, Warszawa 1957, s. 161-162. Analogiczny opis: A. Freitag, Architectura militaris nova et aucta, Amsterdam: D. Elzevier, 1665, s. 127.

${ }^{73}$ Zachował się rękopiśmienny dokument, który można określić jako formę przejściową pomiędzy itinerarium a mapą. Jest to plan drożny do Pskowa Stanisława Pachołowieckiego z 1581 roku. Archivio Segreto Vaticano, Segreteria di Stato, Polonia, sygn. 18, k. 276.

${ }^{74}$ Pomimo tej deklaracji nie zachowały się szesnastowieczne mapy wielkoskalowe prezentujące ziemie wchodzące w skład Mazowsza. A. Bartoszewicz, H. Bartoszewicz, Kartografia miast Mazowsza i ziemi dobrzyńskiej do końca XIX wieku, Warszawa-Pułtusk 2012, s. 24-25.

${ }^{75}$ S. Grzepski, Geometria, to jest miernicka nauka, po polsku krótko napisana $z$ greckich i $z$ łacińskich ksiag, Kraków: Łazarz Andrysowic, 1566, [niepaginowana przedmowa, s. 3] (reprint: Warszawa 1861); por. ibidem, k. Jijv.: „Mierników nawięcey iest $\mathrm{w}$ Mazowszu niż gdzie indzie w Koronie, indzie ich nie tak wiele: a w Polszce trudno sye którego dopytać". 
lonych w swoim fachu ${ }^{76}$. Prawdopodobnie wielka, skoordynowana akcja mierzenia ziemi doprowadziła jednak do upowszechnienia się zawodu i wykształcenia wśród przynajmniej niektórych mierniczych wysokich umiejętności. Przykładem na dobre przygotowanie zawodowe może być mapa dóbr knyszyńskich i rajgrodzko-goniądzkich powstała w latach 1561-1571 (il. 7). Zawiera ona wszelkie niezbędne wojsku informacje, przy tym jest wykonana w przydatnej dla armii skali około $1: 100000^{77}$. Podobną jakość wykonania odnaleźć można wśród map majątkowych powstałych na terenie Warmii. Licznie zachowane źródła kartograficzne pochodzą z lat 1585-1586, kiedy to w dominium biskupim wykonywano działania na wzór litewskiej pomiary włócznej ${ }^{78}$. Niewątpliwie zatem w Wielkim Księstwie Litewskim i Koronie było sporo osób mających umiejętności niezbędne do wykonania map marszrutowych. Przenikanie mierniczych do wojska i wykorzystanie ich umiejętności w służbie wojskowej nie jest dotychczas zbadane i stanowi postulat badawczy ${ }^{79}$.

${ }^{76}$ K. Łopatecki, Organizacja, prawo i dyscyplina w polskim i litewskim pospolitym ruszeniu (do połowy XVII wieku), Białystok 2013, s. 258-259.

77 S. Alexandrowicz, Mapy majątkowe pótnocnego Podlasia $z$ XVI wieku, „Kwartalnik Historii Kultury Materialnej” 14 (1966), nr 2, s. 294-300. Por. idem, W sprawie kartografii wojskowej, w: Materialy $z$ konferencji naukowej historyków wojskowych $w$ Poznaniu poświęconej problematyce metodologicznej w rozwoju polskiej historiografii wojskowej, [red. C. Łuczak], Poznań 1966, s. 107.

${ }^{78}$ A. Pieczunko, Miernictwo i miernicy na Warmii. Szkic do dziejów limitacji pruskiej w średniowieczu i czasach nowożytnych (XIV-XVIII w.), „Komunikaty Mazursko-Warmińskie" 49 (2005), nr 1, s. 10-12; R. Marchwiński, Plany i mapy majątkowe Warmii z lat 1580-1600 w Archiwum Diecezji Warmińskiej w Olsztynie, „Komunikaty Mazursko-Warmińskie” 26 (1982), nr 3, s. 169-186 (w tym reprodukcje 14 map).

${ }^{79}$ Założenie to jest o tyle prawdopodobne, że znakomity gdański kartograf Fryderyk Berndt rozpoczynał swoją karierę właśnie od miernictwa prowadzonego na terenie wsi warmińskich. R. Marchwiński, Plany i mapy..., s. 184. 


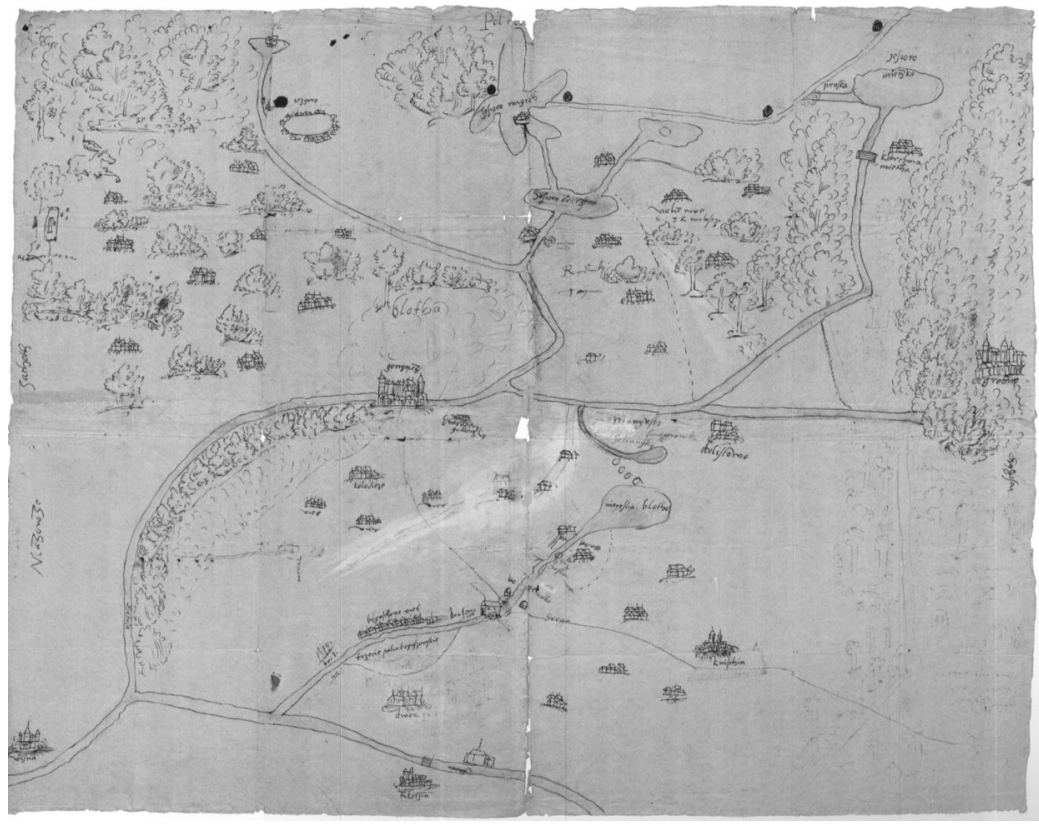

Il. 7. Mapa dóbr knyszyńskich i rajgrodzko-goniądzkich (Biblioteka Uniwersytetu Wileńskiego, f. 23-132)

Innym przykładem możliwości kartograficznych istniejących w okresie panowania Zygmunta II Augusta jest praca Stanisława Porębskiego Ducatus Oswieczimien [sis] et Zatoriensis descriptio (il. 8) ${ }^{80}$. Porębski narysował ją, przygotował płytę miedziorytniczą i opublikował w Wenecji w 1563 roku. Mapa ma format $323 \times 238 \mathrm{~mm}$ i jest przedstawiona w skali $1: 250000^{81}$. Co szczególnie ważne, źródło to

${ }^{80}$ Zamek Królewski w Warszawie - Muzeum, Kolekcja dr. Tomasza Niewodniczańskiego, sygn. TN 2417 (dep. Deutsch-Polnische Stiftung Kulturpflege und Denkmalschutz); zob. też: http://gallica.bnf.fr/ark:/12148/btv1b550050889 (dostęp: 11.12.2016).

${ }^{81}$ S. Alexandrowicz, Najstarsza mapa..., s. 357-372; B. Olszewicz, Kartografia polska..., s. 20; K. Buczek, Dzieje kartografii polskiej od XV do XVIII wieku. Zarys analityczno-syntetyczny, Wrocław 1963, s. 32; T.M. Nowak, Polska artyleria..., s. 121. 
odnotowuje mosty, które miały kluczowe znaczenie dla manewrującej armii. To źródło kartograficzne również potwierdza możliwości wykonania odpowiednich dla wojska materiałów kartograficznych.

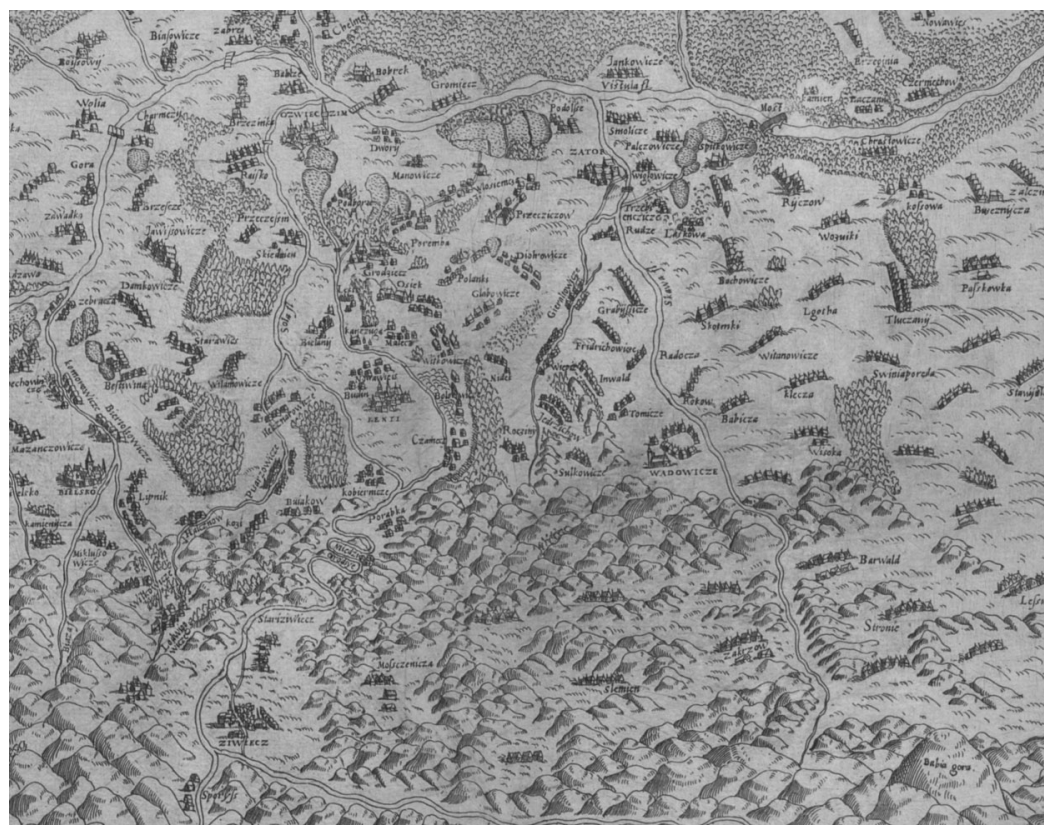

Il. 8. Fragment mapy Księstwa Oświęcimskiego i Zatorskiego Stanisława Porębskiego (Zamek Królewski w Warszawie - Muzeum, Kolekcja dr. Tomasza Niewodniczańskiego, sygn. TN 2417, dep. Deutsch-Polnische Stiftung Kulturpflege und Denkmalschutz, za uprzejmą zgodą Muzeum)

Innym przykładem powstałej na początku drugiej połowy XVI wieku mapy, która mogła posłużyć w podejmowaniu decyzji operacyjnych, była mapa Śląska wykonana w 1561 roku przez Marcina Helviga, a wydrukowana w Nysie przez Jana Creutziga (skala 1:530 000) ${ }^{82}$.

${ }^{82}$ B. Olszewicz, Kartografia polska..., s. 19-20; T.M. Nowak, Polska artyleria..., s. 120-121; R. Wytyczak, Śląsk w dawnej kartografi..., s. 23-24. 
Warto o niej wspomnieć, gdyż mogła ona być doskonałą pomocą przy planowaniu tras przemarszu podczas konfrontacji w 1588 roku sił arcyksięcia Maksymiliana Habsburga z wojskami Jana Zamoyskiego (zob. il. 9a), ostatecznie zakończonej 22 stycznia bitwą pod Byczyną (na mapie Pitzen, zob. il. 9b). Niestety współczesne źródła nie mówią wprost o wykorzystaniu tego źródła kartograficznego ${ }^{83}$.

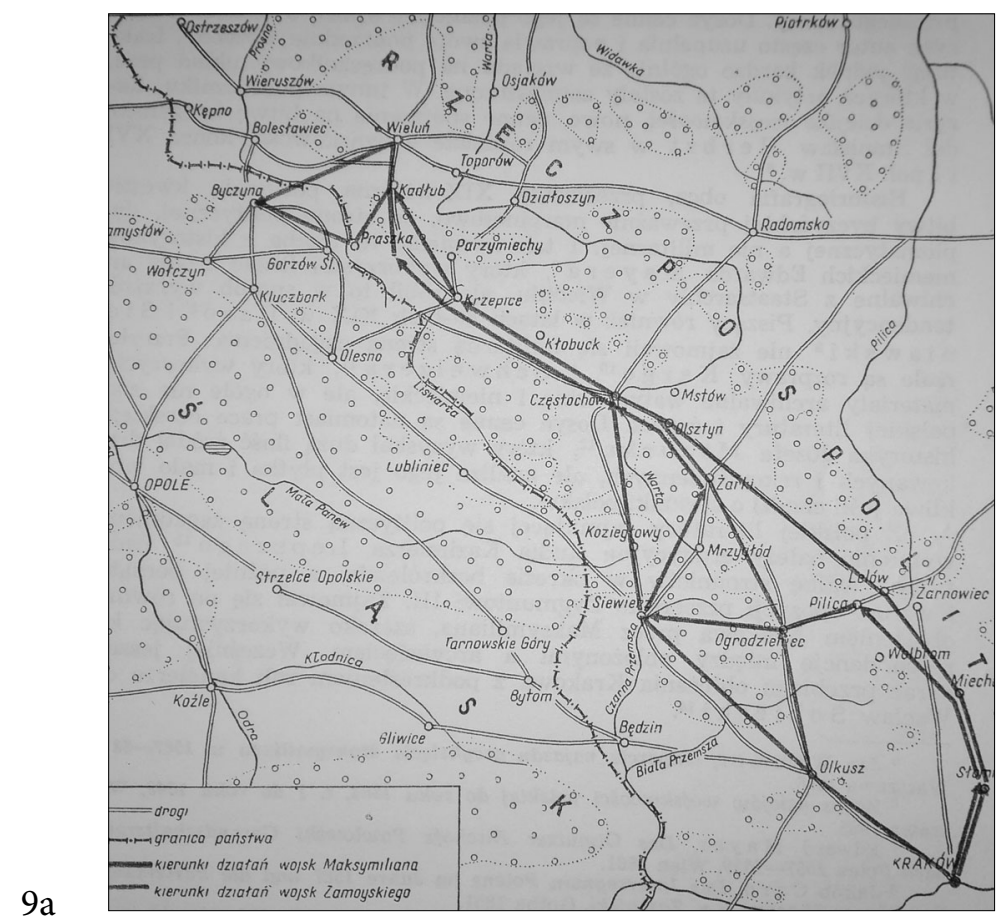

${ }_{83}$ M. Plewczyński, Bitwa pod Byczyna 24.01.1588 r., „Studia i Materiały do Historii Wojskowości” 17 (1971), cz. 1, s. 125-170. 


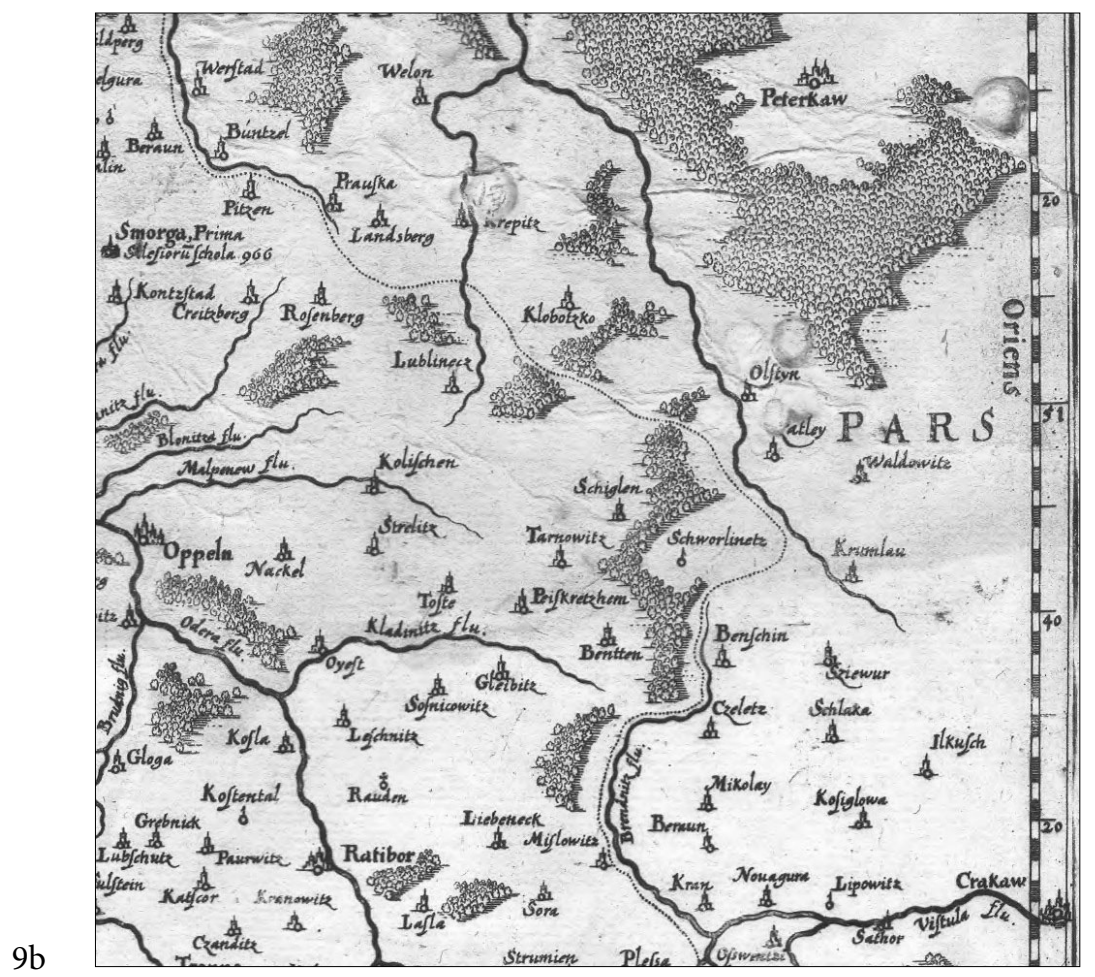

Il. 9a, 9b. Zestawienie trasy przemarszu wojsk Maksymiliana Habsburga i Jana Zamoyskiego w 1588 roku (9a: M. Plewczyński, Bitwa pod Byczyna 24.01.1588 r., „Studia i Materiały do Historii Wojskowości” 17 (1971), cz. 1, s. 129) z fragmentem mapy Marcina Helviga z 1561 roku (9b: Silesia Dvcatvs A. Martino Helwigio Nissense descriptus, [Nysa 1561] (fragment), http://gallica.bnf.fr/ark:/12148/btv1b55004621m/f1.item, dostęp: 11.12.2016) 


\section{Podsumowanie}

1. W XVI i XVII wieku działania operacyjne należy rozumieć jako czynności prowadzone przez samodzielne zgrupowania (najczęściej pułki), możemy je określić jako sztukę manewrową. Jest to taki zespół działań, który sytuuje się pomiędzy decyzjami strategicznymi a konkretnymi czynnościami taktycznymi związanymi z prowadzonymi bitwami czy też oblężeniami. Polegał on na ruchach wojsk od bazy operacyjnej do punktu docelowego po liniach operacyjnych (il. 1). Działanie takie zasadzało się na sprawnym przemieszczaniu się, ale mogło jednocześnie obniżyć sprawność nieprzyjaciela między innymi przez zajęcie lepszego terenu, przecięcie linii dostaw i zaopatrzenia. Źródła kartograficzne o znaczeniu operacyjnym to przede wszystkim mapy marszrutowe powstałe na podstawie itinerariów (il. 6) oraz mapy obszaru obejmujące zarówno bazę, jak i punkt operacyjny (il. 2, 4 i 5).

2. Jednym z pierwszych szesnastowiecznych teoretyków i dowódców, którzy dostrzegali wagę sztuki manewrowej, był Albrecht Hohenzollern. Akcentował on rolę wyprzedzających czynności, które powinny być powierzone grupom rozpoznawczym. Oddziały te miały nie tylko ustalić możliwe trasy przemarszu, wybrać najlepsze miejsca pod obóz wojskowy, lecz powinny także przygotować drogi, zbudować mosty. Powinny one również rozpoznać wojska nieprzyjacielskie, ocenić ich siłę i trasę przemarszu. Działania te możemy określić jako przygotowanie linii operacyjnej. Wyprzedzające działanie o charakterze manewrowym od XVI wieku zgodnie szacowano na jeden dzień. Postulowali to Jan Tarnowski, Albrecht Hohenzollern i Marcin Bielski. Założenie to przetrwało przynajmniej do początków XVIII stulecia.

3. Dobre rozpoznanie zagwarantować mieli również przewodnicy, szpiedzy oraz inżynierowie. Wykorzystywano także wiedzę miejscowej ludności. Grupa rozpoznawcza powinna wykonać 
opisy dróg (itineraria), jednak już Andrzej Frycz Modrzewski w 1551 roku zaproponował wzorem tureckim wykonywanie specjalnych map (il. 2). Oprócz wzorców tureckich powoływano się również na doświadczenia cesarskie. Bartosz Paprocki i Andrzej Gostyński podawali przykład Karola V (1500-1558).

4. Stanisław Łaski był pierwszym autorem, który już w latach 40. XVI wieku akcentował rolę źródeł kartograficznych w działaniach operacyjnych. Był to jednak postulat, nie zaś opis procederu. W pierwszej kolejności powstawały opisy drogowe itineraria. Najstarszy znany przykład powstały na potrzeby wojskowe pochodzi z 1570 roku i zatytułowany jest Wiadomość kędy w ziemię nieprzyjacielska iść (il. 6). Konieczność obecności w wojsku kartografa, który na bieżąco wykonywałby mapy marszrutowe, postulowali tworzący na początku panowania Stefana Batorego Bartosz Paprocki oraz Stanisław Sarnicki.

5. Niezbędne do wykonania map marszrutowych było wdrożenie mierzenia odległości za pomocą kroków, co znacznie ułatwiało rekognoskowanie. Jednostajny krok marszowy pozwalał nawet na ustalenie przebytej drogi na podstawie upływającego czasu ( 1 godzina $=8000$ kroków). W konsekwencji mapy wykonywane na trudnym terenie wskazywały milę jako mniejszy odcinek niż analogiczna jednostka mierzona na dobrze utrzymanym trakcie. Pomocne dla inżynierów w niwelowaniu wyżej wymienionych błędów mogły być pedometry, które liczyły kroki człowieka lub konia (il. 3a i 3b).

6. Marcin Bielski wprowadził do literatury militarnej w dawnej Rzeczypospolitej starorzymską koncepcję kroku podwójnego (passus - $148 \mathrm{~cm}$ ). Prowadziło to do chaosu terminologicznego. W związku $\mathrm{z}$ tym przy badaniu źródeł przynajmniej z końca XVI wieku należy sprawdzać, czy autor źródła pisał o kroku pojedynczym czy podwójnym. Reinhold Heidenstein pod pojęciem kroku rozumiał passus, czyli krok podwójny. Wpływ Bielskiego na twórczość Heidensteina wydaje się duży, co uzewnętrznia się również mierzeniem dziennego 
dystansu przemarszu armii. Autor zwykle ocenia go według podanej przez Bielskiego liczby na 20000 kroków.

7. Przełom kartograficzny w aspekcie działań manewrowych dokonał się podczas działań wojennych przeciw Gdańskowi (1576-1577). Wiemy, że powstało wówczas pięć różnych map i planów, a zachowany rysunek autorstwa Ferdynanda von Schönaicha wskazuje, że z powodzeniem wykorzystywano kartografię przy działaniach operacyjnych (il. 4). Ważnym zabytkiem powstałym na potrzeby wojsk koronnych była mapa odnotowana w Księdze hetmańskiej Sarnickiego. Niestety źródło to nie przetrwało w całości, zachowała się jedynie legenda, która poświadcza, że na mapie zaznaczono miasta (Gdańsk, Pruszcz Gdański i Tczew), sieć rzeczną, mosty i obozy wojskowe zakładane w 1577 roku.

8. Mapy wielkoskalowe wykonywane przez mierników na potrzeby cywilne w połowie XVI stulecia, a także mapa Księstwa Oświęcimskiego i Zatorskiego Stanisława Porębskiego (1563) oraz mapa Śląska wykonana przez Marcina Helviga (1561) poświadczają, że władze polskie i litewskie miały do dyspozycji specjalistów, którzy mogli wypełniać zadania związane z kartograficzną działalnością operacyjną (il. 8, 9a i 9b).

\section{Bibliografia}

\section{Źródła archiwalne}

Российская национальная библиотека, Санкт-Петербург, Ф. 971, Авт. 321/1, № 2 .

Archivio Segreto Vaticano, Segreteria di Stato, Polonia, sygn. 18.

Biblioteka Książąt Czartoryskich w Krakowie, rkps 1813.

Biblioteka PAN w Gdańsku, nr inw. 5664.

Biblioteka PAN w Kórniku, rkps 659, Kampenhauzen J.M.J., Obserwacyje do wojennych operacyj i akcyj. 
Biblioteka Uniwersytetu Wileńskiego, f. 23-132, Mapa dóbr knyszyńskich i rajgrodzko-goniądzkich.

Krigsarkivet, Stockholm, Utländska stads- och fästningsplaner (nr zespołu 406), Tyskland (nr serii 25), Danzig (nr jednostki 44), k. 1.

Topkapı Sarayı Müzesi Arşivi, Istanbul E. 12090/1.

Zamek Królewski w Warszawie - Muzeum, Kolekcja dr. Tomasza Niewodniczańskiego, sygn. TN 2417 (dep. Deutsch-Polnische Stiftung Kulturpflege und Denkmalschutz).

\section{Źródła drukowane}

Behring W., Beiträge zur Geschichte des Jahres 1577. II.: Die Berichte der kursächsischen Gesandten Abraham von Bock und Dr. Andreas Pauli über die Friedensvermittlung zwischen König Stephan Bathory und der Stadt Danzig, „Zeitschrift des Westpreussischen Geschichtsvereins" (Danzig) (1903), H. 45, s. 1-136.

Bellay Du M., Les memoires, Paris: P. L'huillier, 1569.

Bielski M., Sprawa rycerska, w: Archiwum domowe do dziejów literatury krajowej, wyd. K.W. Wójcicki, Warszawa 1856.

Bielski M., Sprawa rycerska według postępku i zachowania starego obyczaju rzymskiego, greckiego, macedońskiego i innych narodow pierwszego i niniejszego wieku tak pogańska jako i krześcijańska z rozmaitych ksiag wypisana ku czytaniu i nauce ludziom rycerskim pożyteczna, Kraków: Mateusz Siebeneicher, 1569.

Broniewski M., Tartariae Descriptio. Opis Tatarii, przeł. E. Śnieżewska, wyd. M. Mączyńska, Łódź 2011.

Broniowski M., Martini Broniovii, de Biezdzfedea Bis In Tartariam Nomine Stephani Primi Poloniae Regis Legati Tartariae Descriptio, Köln: Officina Birckmannica, 1595.

Freitag A., Architectura militaris nova et aucta, Amsterdam: D. Elzevier, 1665.

Grzepski S., Geometria, to jest miernicka nauka, po polsku krótko napisana z greckich i z łacińskich ksiąg, Kraków: Łazarz Andrysowic, 1566 (reprint: Warszawa 1861).

Heidenstein R., Dzieje Polski od śmierci Zygmunta Augusta do roku 1594. Ksiag XII, t. 1, przeł. M. Gliszczyński, Petersburg 1857.

Hogrewe P., Teoryczna i praktyczna nauka żołnierskich rozmiarów, czyli miernictwo wojenne do użycia oficyjerom i początkowym inżenierom, przeł. J. Łęski, Warszawa: Piotr Dufour, 1790.

Kodeks wojskowy Piotra I z 1716 roku, oprac. i przeł. P. Krokosz, K. Łopatecki, Kraków-Oświęcim 2016.

Kopański S., Urywki z pamiętnika, w: Samodzielna Brygada Strzelców Karpackich. Opracowanie zbiorowe żołnierzy SBSK, Warszawa 2014.

Die Kriegsordnung des Markgrafen zu Brandenburg Ansbach und Herzogs zu Preussen Albrecht des Älteren - Königsberg 1555, Bd. 1, hrsg. von H.J. Bömelburg, B. Chiari, M. Thomae, Braunschweig 2006.

Liborius Naker's Tagebuch, hrsg. M. Toeppen, w: Scriptores Rerum Prussicarum, Bd. 5, Leipzig 1874, s. 289-314. 
Liske X., Cudzoziemcy w Polsce, Lwów 1876.

Die Littauischen Wegeberichte, w: Scriptores Rerum Prussicarum, hrsg. von T. Hirsch, M. Töppen, E. Strehlke, Bd. 2, Leipzig 1863, s. 662-708.

Łaski S., Stanisława Łaskiego, wojewody sieradzkiego, prace naukowe i dyplomatyczne, wyd. M. Malinowski, Wilno 1864.

Modrzewski A.F., Commentariorum de republica emendanda libri quinque, Basilea: Johann Oporinus, 1554.

Modrzewski A.F., O poprawie Rzeczypospolitej księgi czwore, przeł. C. Bazylik, Łosk: J. Karcan, 1577.

Naronowicz-Naroński J., Budownictwo wojenne, wyd. J. Nowakowa, Warszawa 1957.

Oelsnitz A.L., O bagażach wojska w polu będacego, oprac. K. Łopatecki, Oświęcim 2014.

Paprocki B., Flawijusza Wegecyjusza Renata męża zacnego o sprawie rycerskiej nauka [...] tłumaczona przez Francizka Paprockiego [...], t. 1, Łowicz 1776.

Paprocki B., Hetman, wyd. K.J. Turowski, Sanok 1856.

Paprocki B., Hetman albo własny konterfekt hetmański, Kraków: Mateusz Siebeneicher, 1578.

Pfinzing P., Methodus geometrica, Nürnberg 1598.

Porębski S., Ducatus Oswieczimen[sis] et Zatoriensis descriptio, Venetia: Libraria del S. Marco, 1563.

Sarnicki S., Księgi hetmańskie, oprac. M. Ferenc, Kraków 2015.

Tarnowski J., Consilium rationis belicae, Tarnów 1558.

Tarnowski J., Consilium rationis belicae, oprac. T.M. Nowak, Warszawa 1987.

Vegetius Renatus F., Abriß des Militärwesens: lateinisch und deutsch, mit Einl., Erl. und Indices von F.L. Müller, Stuttgart 1997.

Wegecjusz Renatus F., Zarys wojskowości ksiag cztery, oprac. i przeł. A.M. Komornicka, „Meander” 28 (1973), nr 10, s. 400-417.

Wybór pism pedagogicznych Polski doby Odrodzenia, wyd. J. Skoczek, Wrocław 1956.

\section{Opracowania}

Abrahamowicz Z., Stara turecka mapa Ukrainy z planem wysadzenia dnieprzańskich porohów i ataku floty tureckiej na Kijów, „Studia Historyczne” 44 (2001), nr 1, s. 3-23.

Alexandrowicz S., Kartografia ziem Wielkiego Księstwa Litewskiego w epoce panowania Jagiellonów, „Polski Przegląd Kartograficzny” 46 (2014), nr 1, s. 62-75.

Alexandrowicz S., Mapy majątkowe północnego Podlasia z XVI wieku, „Kwartalnik Historii Kultury Materialnej" 14 (1966), nr 2, s. 279-305.

Alexandrowicz S., Najstarsza mapa szczegółowa ziem polskich. Stanisława Porębskiego mapa księstwa oświęcimskiego i zatorskiego z 1563 roku, w: Mente et litteris. O kulturze i społeczeństwie wieków średnich, red. H. Chłopocka et al., Poznań 1984, s. 357-372. 
Alexandrowicz S., Rozwój kartografii Wielkiego Księstwa Litewskiego od XV do połowy XVIII wieku, Poznań 1989.

Alexandrowicz S., W sprawie kartografii wojskowej, w: Materiały z konferencji naukowej historyków wojskowych w Poznaniu poświęconej problematyce metodologicznej w rozwoju polskiej historiografii wojskowej, [red. C. Łuczak], Poznań 1966, s. 105-108.

Alexandrowicz S., Buczek K., Polska kartografia wojskowa do połowy XVII wieku, w: Dzieje polskiej kartografii wojskowej i myśli strategicznej. Materiały z konferencji, oprac. B. Krassowski, J. Madej, Warszawa 1982, s. 7-32.

Almonaitis V., Laukuvos apylinkès kryžiuočių karo keliu aprašymy duomenimis, w: Laukuva. Lietuvos valsčiai I, Vilnius 2005, s. 171-183.

Bagrow L., History of Cartography, New Brunswick-London 2010.

Bartoszewicz A., Bartoszewicz H., Kartografia miast Mazowsza i ziemi dobrzyńskiej do końca XIX wieku, Warszawa-Pułtusk 2012.

Bocheński Z., „Złote pióra” na kopiach husarskich, „Broń i Barwa” 6 (1939), nr 5-6.

Bogacz T., Wiedza geograficzna o Śląsku w dobie odrodzenia, Wrocław 1990.

Buczek K., Dzieje kartografii polskiej od XV do XVIII wieku. Zarys analityczno-syntetyczny, Wrocław 1963.

Buczek K., Kartografia polska w czasach Stefana Batorego, „Wiadomości Służby Geograficznej" 7 (1933), z. 2, s. 69-121.

Chrzanowski I., Marcin Bielski. Studyum literackie, Warszawa 1906.

[Dupin P.], O fizyczney sile człowieka, i iey użyciu pod względem przemysłowym, „Izys Polska czyli Dziennik umiejętności, wynalazków, kunsztów i rękodzieł” 1 (1827), cz. 1, s. 1-21.

Englisch B., Erhard Etzlaub's Projection and Methods of Mapping, „Imago Mundi” 48 (1996), s. 103-123.

Ferenc M., Wstęp, w: S. Sarnicki, Księgi hetmańskie, oprac. M. Ferenc, Kraków 2015.

Furman M., „Sprawa rycerska” Marcina Bielskiego - staropolski traktat czy podrecznik wojskowy?, w: Studia nad staropolska sztuka wojenna, t. 2, red. Z. Hundert, Oświęcim 2013.

Gębarowicz M., Niektóre zagadnienia metodologii historii sztuki (cz. II), „Biuletyn Historii Sztuki” 38 (1976), nr 4, s. 329-355.

Herbst S., Potrzeba historii, t. 2, Warszawa 1978.

Hermann H., Operacyjny wymiar walki zbrojnej, Toruń 2004.

Karamustafa A.T., Military, Administrative, and Scholarly Maps and Plans, w: The History of Cartography, vol. 2, book 1: Cartography in the Traditional Islamic and South Asian Societies, ed. by J.B. Harley, D. Woodward, Chicago-London 1992, s. 209-227.

Kołodziejczyk D., The Crimean Khanate and Poland-Lithuania. International Diplomacy on the European Periphery (15 $15^{\text {th }} 18^{\text {th }}$ Century). A Study of Peace Treaties Followed by Annotated Documents, Leiden 2011.

Korolko M., Andrzej Frycz Modrzewski: humanista, pisarz, Warszawa 1978. 
Korzon T., Dzieje wojen i wojskowości w Polsce. Epoka przedrozbiorowa, t. 1-2, Kraków 1912 (reprint: Poznań 2003).

Kośmider T., Ślipiec J., Operacje wojsk lądowych $w$ pogladach przedstawicieli europejskiej myśli wojskowej od XVIII wieku do wybuchu drugiej wojny światowej, Warszawa 2008.

Łopatecki K., Organizacja, prawo i dyscyplina w polskim i litewskim pospolitym ruszeniu (do połowy XVII wieku), Białystok 2013.

Łopatecki K., Prace kartograficzne wykonane na ziemiach Rzeczypospolitej przez szwedzkich inżynierów wojskowych w XVII stuleciu, „Studia i Materiały do Historii Wojskowości” 46 (2009), s. 55-80.

Łopatecki K., Wyprawa zbrojna Krzysztofa Radziwiłła „Pioruna” w Inflantach zima 1579 roku, „Zapiski Historyczne” 83 (2018), z. 1, s. 39-67.

Łopatecki K., Walczak W., Mapy i plany Rzeczypospolitej XVII w. znajdujace się w archiwach $w$ Sztokholmie. Maps and Plans of the Polish Commonwealth of the $17^{\text {th }} \mathrm{c}$. in Archives in Stockholm, t. 1, Warszawa 2011.

Marchwiński R., Plany i mapy majątkowe Warmii z lat 1580-1600 w Archiwum Diecezji Warmińskiej w Olsztynie, „Komunikaty Mazursko-Warmińskie” 26 (1982), nr 3, s. 169-186.

Maroń J., Kłuszyn i Cudnów a operacyjny wymiar wojny w epoce wczesnonowożytnej, w: Studia z dziejów stosunków Rzeczypospolitej z Państwem Moskiewskim w XVI-XVII wieku, red. M. Nagielski, K. Bobiatyński, P. Gawron, Zabrze-Tarnowskie Góry 2013, s. 278-289.

Minow H., Historische Vermessungsinstrumente. Ein Verzeichnis der Sammlungen in Europa, Wiesbaden 1990.

Mossor S., Sztuka wojenna w warunkach nowoczesnej wojny, Warszawa 1986.

Nowak T.M., Polska artyleria, inżynieria i kartografia wojskowa XVII w. - teoria i praktyka, „Studia i Materiały do Historii Wojskowości” 22 (1979), s. 65-130.

Nowak T.M., Szwedzkie źródło kartograficzne ukazujące trase przemarszu armii M.G. de la Gardie ze Żmudzi na Mazowsze w 1655 r., „Studia i Materiały do Historii Wojskowości” 30 (1988), s. 321-350.

Nowak T.M., Uwagi o technice budowy mostów polowych $w$ Polsce $w$ w. XV do XVII, „Studia i Materiały do Historii Sztuki Wojennej” 2 (1956), s. 345-387.

Nożko K., Walka o przewage, Warszawa 1985.

Olszewicz B., Kartografia polska XV-XVII wieku (przegląd chronologiczno-bibliograficzny), oprac. J. Ostrowski, Warszawa 2004.

Olszewicz B., Wzmianki o znaczeniu map w literaturze Polskiej XVI wieku, „Acta Universitatis Wratislaviensis. Studia Geograficzne" 9 (1963), s. 129-140.

Parucki Z., Zarys geografii wojennej, Warszawa 1967.

Pieczunko A., Miernictwo i miernicy na Warmii. Szkic do dziejów limitacji pruskiej w średniowieczu i czasach nowożytnych (XIV-XVIII w.), „Komunikaty Mazursko-Warmińskie" 49 (2005), nr 1, s. 3-15. 
Pietkiewicz J., Mapa księstwa oświęcimskiego i zatorskiego Stanisława Porębskiego (1563), w: [S. Pietkiewicz, G. Kwiatkowska-Gadomska], Studia nad dokładnościa dawnych map ziem polskich. Trzy mapy z XVI i XVII wieku, Warszawa 1980 (Studia i Materiały do Dziejów Nauki Polskiej. Seria C, z. 24), s. 63-78.

Pietkiewicz S., [Dyskusja], w: Dzieje polskiej kartografii wojskowej i myśli strategicznej. Materiały z konferencji, red. B. Krassowski, J. Madej, Warszawa 1982, s. 161.

Plewczyński M., Bitwa pod Byczyna 24.01.1588 r., „Studia i Materiały do Historii Wojskowości” 17 (1971), cz. 1, s. 125-170.

Polak A., Sztuka wojenna. Kontekst teoretyczny i praktyczny, „Zeszyty Naukowe AON" (2013), nr 3(92), s. 219-228.

Rogers J.M., Itineraries and Town Views in Ottoman Histories, w: The History of Cartography, vol. 2, book 1: Cartography in the Traditional Islamic and South Asian Societies, ed. by J.B. Harley, D. Woodward, Chicago-London 1992, s. 228-255.

Rothenberg G.E., Maurice of Nassau, Gustavus Adolphus, Raimondo Montecuccoli, and the "Military Revolution" of the Seventeenth Century, w: Makers of Modern Strategy. From Machiavelli to the Nuclear Age, ed. by P. Paret, Princeton 1986, s. 32-63.

Sikorski J., Polskie piśmiennictwo wojskowe od XV do XX wieku, Warszawa 1991.

Soucek S., Islamic Charting in the Mediterranean, w: The History of Cartography, vol. 2, book 1: Cartography in the Traditional Islamic and South Asian Societies, ed. by J.B. Harley, D. Woodward, Chicago-London 1992, s. 263-292.

Ślipiec J., Kośmider T., Generał Henry Humphrey Evans Lloyd - jako prekursor teorii operacji w europejskiej myśli wojskowej. (Doświadczenia), „Myśl Wojskowa” 62 (2006), nr 6, s. 169-178.

Vann J., Mapping Under the Austrian Habsburgs, w: Monarchs, Ministers and Maps. The Emergence of Cartography as a Tool of Government in Early Modern Europe, ed. by D. Buisseret, Chicago-London 1992, s. 153-167.

Vego M.N., Joint Operational Warfare. Theory and Practice, Newport 2007.

Wiatr M., Między strategia a taktyką, Toruń 1999, s. 153-167.

Wytyczak R., Śląsk $w$ dawnej kartografii. Obraz Śląska na mapach XVI-XVIII wieku w zbiorach Zakładu Narodowego im. Ossolińskich we Wrocławiu, Wrocław 1998.

Zagrodzki T., Regularny plan miasta średniowiecznego a limitacja miernicza, Wrocław 1962.

Zarębska T., Początki polskiego piśmiennictwa urbanistycznego, Warszawa 1975.

Zieliński J., Zarys teorii sztuki operacyjnej wojsk lądowych Rzeczpospolitej Polskiej, Toruń 1998.

\section{Źródła internetowe}

Kitab-ı Bahriye, http://art.thewalters.org/detail/19195 (dostęp: 12.05.2016).

Porębski S., Ducatus Oswieczimien[sis] et Zatoriensis descriptio, http://gallica.bnf.fr/ ark:/12148/btv1b550050889 (dostęp: 11.12.2016).

Silesia Dvcatvs A. Martino Helwigio Nissense descriptus, [Nysa 1561], http://gallica. bnf.fr/ark:/12148/btv1b55004621m/f1.item (dostęp: 11.12.2016). 